\title{
Integrated Leaching and Separation of Metals Using Mixtures of Organic Acids and Ionic Liquids
}

\author{
Silvia J. R. Vargas, Helena Passos $(\mathbb{1}$, Nicolas Schaeffer *(i) and João A. P. Coutinho \\ CICECO-Aveiro Institute of Materials, Department of Chemistry, University of Aveiro, \\ 3810-193 Aveiro, Portugal; silvia.vargas@ua.pt (S.J.R.V.); hpassos@ua.pt (H.P.); jcoutinho@ua.pt (J.A.P.C.) \\ * Correspondence: nicolas.schaeffer@ua.pt \\ Academic Editors: Magdalena Regel-Rosocka and Isabelle Billard \\ Received: 4 November 2020; Accepted: 25 November 2020; Published: 27 November 2020

\begin{abstract}
In this work, the aqueous phase diagram for the mixture of the hydrophilic tributyltetradecyl phosphonium $\left(\left[\mathrm{P}_{44414}\right] \mathrm{Cl}\right)$ ionic liquid with acetic acid $\left(\mathrm{CH}_{3} \mathrm{COOH}\right)$ is determined, and the temperature dependency of the biphasic region established. Molecular dynamic simulations of the $\left[\mathrm{P}_{44414}\right] \mathrm{Cl}+$ $\mathrm{CH}_{3} \mathrm{COOH}+\mathrm{H}_{2} \mathrm{O}$ system indicate that the occurrence of a closed "type 0 " biphasic regime is due to a "washing-out" phenomenon upon addition of water, resulting in solvophobic segregation of the $\left[\mathrm{P}_{44414}\right] \mathrm{Cl}$. The solubility of various metal oxides in the anhydrous $\left[\mathrm{P}_{44414}\right] \mathrm{Cl}+\mathrm{CH}_{3} \mathrm{COOH}$ system was determined, with the system presenting a good selectivity for $\mathrm{CoO}$. Integration of the separation step was demonstrated through the addition of water, yielding a biphasic regime. Finally, the $\left[\mathrm{P}_{44414}\right] \mathrm{Cl}+$ $\mathrm{CH}_{3} \mathrm{COOH}$ system was applied to the treatment of real waste, NiMH battery black mass, being shown that it allows an efficient separation of $\mathrm{Co}(\mathrm{II})$ from $\mathrm{Ni}(\mathrm{II}), \mathrm{Fe}(\mathrm{III})$ and the lanthanides in a single leaching and separation step.
\end{abstract}

Keywords: critical metals; process intensification; metal leaching; solvent extraction; solvometallurgy

\section{Introduction}

Solvometallurgy, the extraction of metals from primary and secondary sources using solutions containing less than 50 vol. \% of water, can offer complementary advantages to hydrometallurgical processes. These include the potential integration of the leaching and solvent extraction in a single step as well as a greater leaching selectivity compared to acidic aqueous solutions thereby simplifying subsequent purification steps [1]. For example, simple organic solutions were shown to selectively dissolve gold and platinum group metals with high dissolution rates under mild conditions, thereby providing a more benign alternative to the aggressive aqua regia or cyanidation processes [2,3]. A promising subset of solvometallurgy is ionometallurgy—the processing of metals using solvents containing a high concentration of ions such as ionic liquids (ILs) or deep eutectic solvents (DES) [4]. The important concentration of coordinating anions of most common ionic solvent combined with their low water to ion ratio stabilizes certain metal complexes [5,6] and allows for dissolution reactions and selectivities typically not achievable in aqueous media [7-11].

The versatility and facile preparation of binary mixtures of an ionic compound with an organic acid has resulted in their widespread application as alternative solvents for metal leaching and electrodeposition applications [7,12-19], and to a lesser extent solvent extraction [20-22]. Such mixtures were successfully applied to the treatment of real matrices including sulphidic and oxide ores such as pyrite, chalcopyrite or goethite [8-10,23], zinc flue dust [11], incinerated sewage sludge ash [24], NdFeB magnets [25], NiMH batteries [26] and lithium-ion batteries [27,28]. Notwithstanding the obvious success of these ionic solvents, a persistent issue remains the selective separation of metals with similar properties and redox potentials, often requiring additional separation steps or their recovery 
as mixed products $[10,11,25,26,29]$. Furthermore, it was shown that increasing the complexity of the separation system, can result in the destruction of the mixture integrity and the nonstoichiometric partition of the components between the coexisting phases [30,31]. The development of simple binary mixtures capable of integrating leaching and solvent extraction operations in a single solution by presenting a variable hydrophilic/hydrophobic character with no additional extractant, organic phase or salts could extend the applicability of ionometallurgy. Mixtures of two fully hydrophilic constituents could present additional benefits stemming from the extra degree of tunability provided by small quantities of water in ionic solvents [23,32,33].

Bulky quaternary ammonium and phosphonium ILs such as tetrabutylammonium chloride $\left(\left[\mathrm{N}_{4444}\right] \mathrm{Cl}\right)$ or tetrabutylphosphonium chloride $\left(\left[\mathrm{P}_{4444}\right] \mathrm{Cl}\right)$ are common constituents of hydrophilic and hydrophobic mixtures with organic acids despite both salts being fully water-miscible [34]. Most surprisingly for ionic compounds, certain of these hydrophilic quaternary salts including $\left[\mathrm{P}_{4444}\right] \mathrm{Cl}$ and its surfactant derivative tributyltetradecylphosphonium chloride $\left(\left[\mathrm{P}_{44414}\right] \mathrm{Cl}\right)$ present a pronounced lower critical solution temperature (LCST) in the presence of water [35-38]. The temperature-dependent phase demixing combined with the reported miscibility of quaternary halide salts and numerous organic acids [34] opens up the possibility of reversibly varying the system from monophasic to biphasic through the addition of water and/or temperature manipulation. Such versatile systems could facilitate the integration of leaching and solvent extraction unit operations, providing a bridge between hydrophylic and hydrophobic solvents. Although no such systems were applied to metal recovery, the mixture of lidocaine and oleic acid presents an LCST of $298 \mathrm{~K}$ driven by the change in ionicity from oleate to oleic acid with temperature increase. The mixture was shown to efficiently extract a range of dyes from aqueous solutions [39].

In this work, the phase diagram of the IL $\left[\mathrm{P}_{444414}\right] \mathrm{Cl}$ with acetic acid $\left(\mathrm{CH}_{3} \mathrm{COOH}\right)$ is experimentally and computationally characterized and the mixture applied to the integrated leaching and separation of cobalt from other metals present in Nickel Metal Hydride (NiMH) batteries. Cobalt is a critical metal of high economic importance with demand forecasted to grow due to its inclusion in energy storage technologies, making its recovery from secondary sources increasingly topical [40,41]. Integration of the leaching and separation steps was demonstrated through the simple addition of water, yielding a closed biphasic regime.

\section{Results and Discussion}

\subsection{Characterisation of the $\left[\mathrm{P}_{44414}\right] \mathrm{Cl}+\mathrm{CH}_{3} \mathrm{COOH}+\mathrm{H}_{2} \mathrm{O}$ System}

In an effort to identify potential mixtures capable of presenting a variable hydrophilic/hydrophobic character in the absence of an additional salting-out agent, four aqueous solutions of chloride-based ILs $\left(\left[\mathrm{N}_{4444}\right] \mathrm{Cl},\left[\mathrm{P}_{4444}\right] \mathrm{Cl},\left[\mathrm{P}_{44414}\right] \mathrm{Cl}\right.$ and $\left.\left[\mathrm{C}_{14} \mathrm{mim}\right] \mathrm{Cl}\right)$ and three organic acids were screened for the existence of a biphasic regime. The quaternary ammonium and phosphonium salts were selected due to their reported temperature-dependent aqueous solubility conferred by the screening of the charge center by the alkyl moieties [35-38]. Furthermore, comparing the behavior of the symmetric $\left[\mathrm{P}_{4444}\right] \mathrm{Cl}$ to its surfactant counterpart $\left[\mathrm{P}_{44414}\right] \mathrm{Cl}$ in the presence of organic acids allows to determine the contribution of the IL self-organization on the phase separation. Conversely, the comparison of $\left[\mathrm{P}_{44414}\right] \mathrm{Cl}$ with $\left[\mathrm{C}_{14} \mathrm{mim}\right] \mathrm{Cl}$ permits the evaluation of the surfactant head group, with $\left[\mathrm{C}_{14} \mathrm{mim}\right] \mathrm{Cl}$ displaying an un-screened charge dispersed around the imidazolium ring. Regarding the biodegradable organic acids, acetic acid, lactic acid and the poly-carboxylic citric acid were studied. These acids were selected due to their reported application both in aqueous solutions and as components in eutectic solvents $[13,15,42,43]$. It is important to emphasise that the tested acids present a range of acidities, with their deprotonation constant (pKa) ranking as: citric acid (3.13) < lactic acid (3.86) < acetic acid (4.75). The possibility for acid deprotonation and subsequent anion-exchange with the IL's chloride and the formation of a new and potentially hydrophobic IL must be considered. 
From an initial screening of the ternary systems, only mixtures of $\left[\mathrm{P}_{44414}\right] \mathrm{Cl}$ with acetic acid were found to form biphasic systems, with all others remaining monophasic under the explored conditions. The screening results hint at three prerequisites for the formation of mixtures presenting variable hydrophilicity. Firstly, of the quaternary ammonium and phosphonium salts tested $\left[\mathrm{P}_{44414}\right] \mathrm{Cl}$ is the only one capable of self-assembly into distinct phases in aqueous solution [36,38]. Secondly, a comparison with $\left[\mathrm{C}_{14} \mathrm{mim}\right] \mathrm{Cl}$, which did not form any biphasic systems with the tested acids, indicates that IL self-assembly alone is not sufficient. Thirdly, acetic acid possesses a distinct apolar end section and a low deprotonation constant. The possible interactions between $\mathrm{CH}_{3} \mathrm{COOH}$ and $\left[\mathrm{P}_{44414}\right] \mathrm{Cl}$ yielding to a biphasic system formation are discussed further in the next sections. There are some structural similarities between the investigated $\left[\mathrm{P}_{44414}\right] \mathrm{Cl}+\mathrm{CH}_{3} \mathrm{COOH}$ and the previously-reported $\left[\mathrm{N}_{4444}\right] \mathrm{Cl}+$ decanoic acid $[44,45]$, with the long alkyl chain switched from the organic acid to the IL component. However, contrary to the poorly water-soluble decanoic acid, both $\left[\mathrm{P}_{44414}\right] \mathrm{Cl}$ and acetic acid are water-miscible.

The aqueous phase diagram of $\left[\mathrm{P}_{44414}\right] \mathrm{Cl}$ with $\mathrm{CH}_{3} \mathrm{COOH}$ is presented in Figure $1 \mathrm{~A}$. Prior to any discussion, it is important to stress that $\left[\mathrm{P}_{44414}\right] \mathrm{Cl}$ is soluble in $\mathrm{CH}_{3} \mathrm{COOH}$ in the absence of water along the entire composition range, yielding a homogenous solution liquid at room temperature. This is markedly different to the reported acid aqueous biphasic systems of $\left[\mathrm{P}_{44414}\right] \mathrm{Cl}$ with inorganic acids such as $\mathrm{HCl}$, with the inorganic acid acting as a salting-out for $\left[\mathrm{P}_{44414}\right] \mathrm{Cl}$ resulting in a biphasic system at high acid concentrations [38,46]. The divergence in the underlying mechanism of phase separation in the $\left[\mathrm{P}_{44414}\right] \mathrm{Cl}+\mathrm{CH}_{3} \mathrm{COOH}+\mathrm{H}_{2} \mathrm{O}$ system is evidenced by its unusual closed "Type 0" phase diagram. "Type 0" diagrams are characterized by an immiscibility gap in the ternary region while all the binary mixtures are fully miscible [47]. The formation of aqueous biphasic systems using ionizable species, such as $\left[\mathrm{P}_{44414}\right] \mathrm{Cl}$ and acetic acids, leads to a complex system with potentially five species (four ionic + water). Specifically, the extent of carboxylate anion concentration depends on the acid pKa and solution $\mathrm{pH}$. The $\mathrm{pH}$ of the studied systems never exceeded 3.5, implying that acetic acid $(\mathrm{pKa}=4.75)$ can be primarily considered as the protonated non-ionic specie.
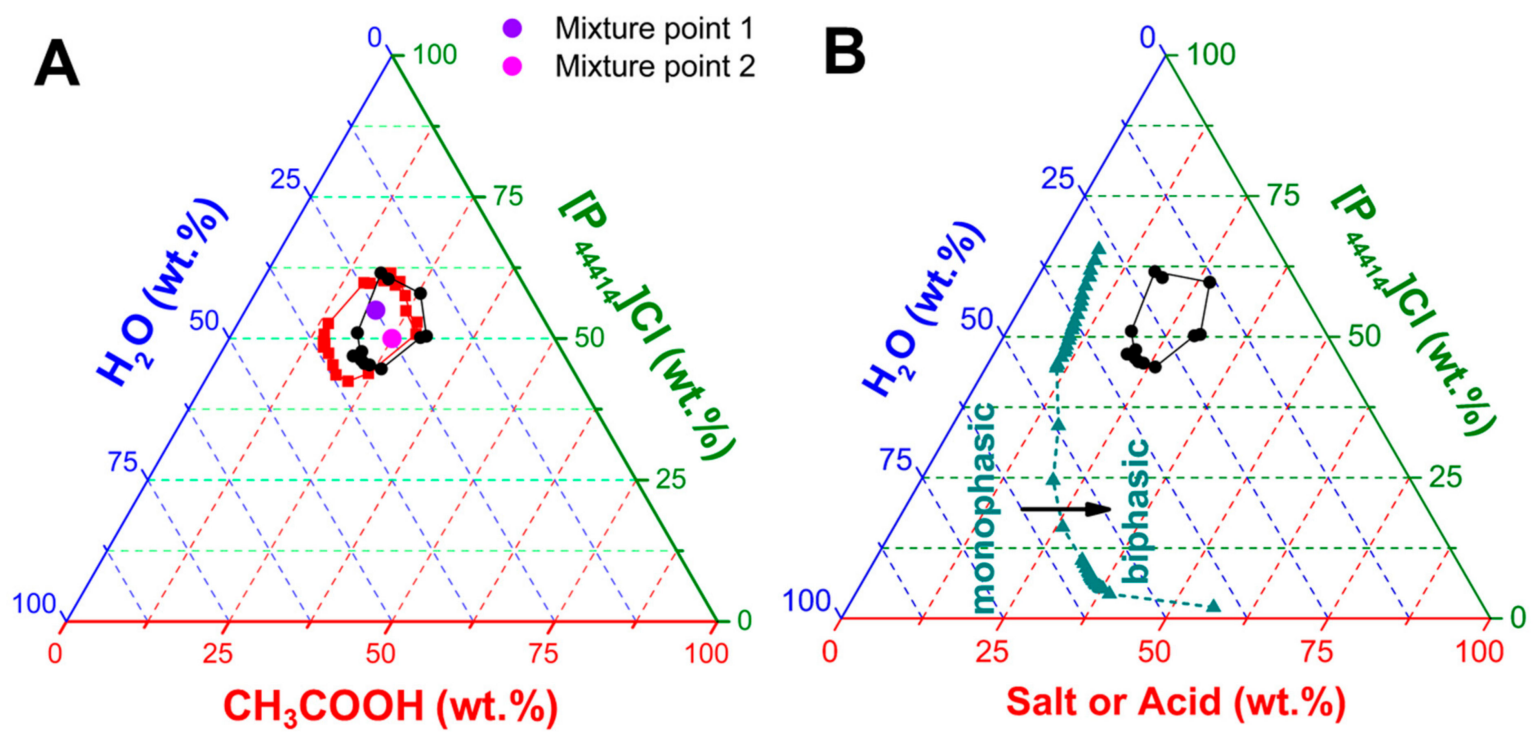

Figure 1. (A) Phase diagram of the $\left[\mathrm{P}_{44414}\right] \mathrm{Cl}+\mathrm{CH}_{3} \mathrm{COOH}+\mathrm{H}_{2} \mathrm{O}$ system at $298 \mathrm{~K}(-$ black) and $323 \mathrm{~K}(\square$ red). (B) Comparison of the experimental phase diagrams for the aqueous biphasic system composed of $\left[\mathrm{P}_{44414}\right] \mathrm{Cl}$ and $\mathrm{CH}_{3} \mathrm{COOH}$ or $\mathrm{NH}_{4} \mathrm{CH}_{3} \mathrm{COO}(\Delta$ cyan) at $298 \mathrm{~K}$.

The appearance of a "type 0 " biphasic system is unusual as such behavior is traditionally associated with polymer-IL type aqueous biphasic systems (ABS) [47-49]. The phase diagrams here reported differing drastically from the more traditional salt-salt mixtures as exemplified by the comparison of the $\left[\mathrm{P}_{44414}\right] \mathrm{Cl}+\mathrm{CH}_{3} \mathrm{COOH}+\mathrm{H}_{2} \mathrm{O}$ with the partial phase diagram of the corresponding ammonium 
acetate salt system in Figure 1B. The latter does not present a closed biphasic region unlike in the $\left[\mathrm{P}_{44414}\right] \mathrm{Cl}+\mathrm{CH}_{3} \mathrm{COOH}+\mathrm{H}_{2} \mathrm{O}$ system but rather a large immiscibility range-restricted at high salt concentrations by the solubility limit of $\mathrm{NH}_{4} \mathrm{CH}_{3} \mathrm{COO}$. Comparison of the phase diagrams in Figure $1 \mathrm{~B}$ contrasts the distinct salting-out influence exerted by the negatively charged acetate anion and the neutral protonated acetic acid. The inherent LCST properties of $\left[\mathrm{P}_{44414}\right] \mathrm{Cl}$ are maintained in the $\left[\mathrm{P}_{44414}\right] \mathrm{Cl}+\mathrm{CH}_{3} \mathrm{COOH}+\mathrm{H}_{2} \mathrm{O}$ system, Figure $1 \mathrm{~A}$, with an increase in the experimentally determined biphasic area with a temperature increase from 298 to $323 \mathrm{~K}$. This contrasts with the upper critical solution temperature (UCST) behavior observed in polymer-IL type ABS where the immiscibility region decreases with increased temperature [47]. The "type 0" diagrams in Figure 1 represent an interesting separation approach for an integrated leaching/separation, where one can move from the pure mixture under the monophasic condition to a biphasic regime for separation through the simple addition of water and temperature manipulation.

For selected mixture points in the biphasic regime at $323 \mathrm{~K}$, shown in Figure 1A, the concentration of the $\left[\mathrm{P}_{44414}\right]^{+}$cation and acid concentration were measured in both phases and reported in Table 1. Results indicate the preferential partition of the $\left[\mathrm{P}_{44414}\right] \mathrm{Cl}$ to one phase, with an almost quantitative distribution independent of the mixture point. Interestingly, acetic acid appears to distribute between the two phases, Table 1, despite its relative hydrophilicity with an octanol/water partition coefficients $\left(\mathrm{K}_{\mathrm{OW}}\right)$ of $\log \left(\mathrm{K}_{\mathrm{OW}}\right)=-0.17$ [50]. Such partitioning is noticeably different from that observed in salt-IL ABS where the IL and inorganic salt accumulate in opposite phases. The protonated carboxylic acid does not present a traditional salting-out inducing nature, yet the mixture of $\left[\mathrm{P}_{44414}\right] \mathrm{Cl}$ with $\mathrm{CH}_{3} \mathrm{COOH}$ presents a synergistic enhancement in hydrophobicity despite both individual components being fully miscible in water. Rather, the observed trend in Table 1 is reminiscent of the observed phase separation in $\left[\mathrm{P}_{4444}\right] \mathrm{Cl}$-based hydrotrope system with gallic acid or vanillin as solute [51]. Such systems, above a certain solute concentration, phase-separated into a phase concentrated in both IL and solute and a diluted phase. Importantly for the reusability of the $\left[\mathrm{P}_{44414}\right] \mathrm{Cl}+\mathrm{CH}_{3} \mathrm{COOH}$ systems, results in Table 1 indicate the loss of the original mixture composition. This can be partially mitigated in the presence of salts, promoting the partition of acetic acid to the IL-rich phase as shown in Table 1.

Table 1. Quantification of phase composition for the aqueous biphasic system composed of $\left[\mathrm{P}_{44414}\right] \mathrm{Cl}$ and $\mathrm{CH}_{3} \mathrm{COOH}$ at $313 \mathrm{~K}$ (TLL-Tie Line Length). The mixture point $1^{*}$ has the same initial $\left[\mathrm{P}_{44414}\right] \mathrm{Cl}$ and $\mathrm{CH}_{3} \mathrm{COOH}$ concentration as mixture point 1 plus $2.00 \mathrm{wt} . \% \mathrm{NaCl}$.

\begin{tabular}{ccccccccccccccc}
\hline \multirow{2}{*}{$\begin{array}{c}\text { Mixture } \\
\text { Point }\end{array}$} & \multicolumn{3}{c}{ Total Composition (wt.\%) } & \multicolumn{4}{c}{ Top Phase (wt.\%) } & \multicolumn{4}{c}{ Bottom Phase (wt.\%) } & TLL \\
\cline { 2 - 5 } & IL & Acid & $\mathbf{H}_{\mathbf{2}} \mathbf{O}$ & IL & Acid & $\mathbf{H}_{\mathbf{2}} \mathbf{O}$ & $\begin{array}{c}\text { Vol } \\
(\mathbf{m L})\end{array}$ & IL & Acid & $\mathbf{H}_{\mathbf{2}} \mathbf{O}$ & $\begin{array}{c}\text { Vol } \\
(\mathbf{m L})\end{array}$ \\
\hline 1 & 55.00 & 20.00 & 25.00 & 49.02 & 12.00 & 38.98 & 2.0 & 1.41 & 25.31 & 73.27 & 0.4 & 49.43 \\
$1^{*}$ & 55.00 & 20.00 & 23.00 & 64.81 & 26.15 & 9.04 & 1.9 & 0.01 & 13.72 & 86.27 & 0.5 & - \\
2 & 50.00 & 25.00 & 25.00 & 69.77 & 24.08 & 6.15 & 2.0 & 0.10 & 30.72 & 69.18 & 0.4 & 69.99 \\
\hline
\end{tabular}

\subsection{Mechanism of Phase Separation in the $\left[\mathrm{P}_{44414}\right] \mathrm{Cl}+\mathrm{CH}_{3} \mathrm{COOH}+\mathrm{H}_{2} \mathrm{O}$ System}

To better understand the underlying mechanism of phase separation in the studied systems, the $\left[\mathrm{P}_{44414}\right] \mathrm{Cl}+\mathrm{CH}_{3} \mathrm{COOH}$ system for a fixed molar ratio was simulated by classical all-atom (AA) molecular dynamics (MD) for various hydration levels from pure to diluted. The compositions of the systems simulated are summarised in Table 2 and $\mathrm{CH}_{3} \mathrm{COOH}$ was considered as fully protonated throughout. 
Table 2. $\left[\mathrm{P}_{44414}\right] \mathrm{Cl}+\mathrm{CH}_{3} \mathrm{COOH}+\mathrm{H}_{2} \mathrm{O}$ system composition for all AA simulations at $323 \mathrm{~K}$. All systems contain $200\left[\mathrm{P}_{44414}\right] \mathrm{Cl}$ ion pairs and $\mathrm{CH}_{3} \mathrm{COOH}$ molecules with an increasing number of water molecules $\left(\mathrm{n}\left(\mathrm{H}_{2} \mathrm{O}\right)\right)$.

\begin{tabular}{cccccc}
\hline System & $\mathbf{n}\left(\mathbf{H}_{\mathbf{2}} \mathbf{O}\right)$ & $[\mathbf{I L}] \mathbf{( w t .} \%)$ & {$\left[\mathbf{C H}_{\mathbf{3}} \mathbf{C O O H}\right] \mathbf{( w t . \% )}$} & $\left.\left[\mathbf{H}_{\mathbf{2}} \mathbf{O}\right] \mathbf{( w t .} \%\right)$ & Experimental Regime \\
\hline$(1)$ & 0 & 71.4 & 28.6 & 0.0 & Monophasic \\
$(2)$ & 363 & 67.8 & 27.1 & 5.1 & Monophasic \\
$(3)$ & 725 & 64.5 & 25.8 & 9.7 & Monophasic \\
$(4)$ & 1450 & 58.8 & 23.5 & 17.7 & Biphasic \\
$(5)$ & 2900 & 50.0 & 20.0 & 30.0 & Biphasic \\
$(6)$ & 5800 & 38.4 & 15.4 & 46.2 & Monophasic \\
$(7)$ & 14,500 & 22.7 & 9.1 & 68.2 & Monophasic \\
\hline
\end{tabular}

The structure of the $\left[\mathrm{P}_{44414}\right] \mathrm{Cl}+\mathrm{CH}_{3} \mathrm{COOH}$ system in the absence of water, shown in Figure 2A, is visually characterized by a distinct nano-segregation into polar and apolar domains consisting of bi-continuous $\left[\mathrm{P}_{44414}\right]^{+}$aggregates and a percolating polar hydrogen-bonded network of chloride anion and acetic acid. Radial distribution function (RDF) analysis in Figure 2B indicates hydrogen-bonded $\mathrm{CH}_{3} \mathrm{COOH} \cdots \mathrm{Cl}^{-}$and $\mathrm{CH}_{3} \mathrm{COOH} \cdots \mathrm{OHOCCH}_{3}$ carboxylic dimer as the predominant short-range interactions $(\leq 0.3 \mathrm{~nm})$, stabilized by longer-range IL cation-anion electrostatic interactions. The shielded nature of the $\left[\mathrm{P}_{44414}\right]^{+}$phosphorus charge center liberates the chloride anion to closely interact with the carboxylic acid and limits short-range Coulombic contributions. Furthermore, significant dispersive interaction between acetic acid and the butyl chains of the $\left[\mathrm{P}_{44414}\right]^{+}$polar head are observed, reaching inside the $\left[\mathrm{P}_{44414}\right]^{+}$aggregates as shown in the spatial distribution function representation in Figure S1.
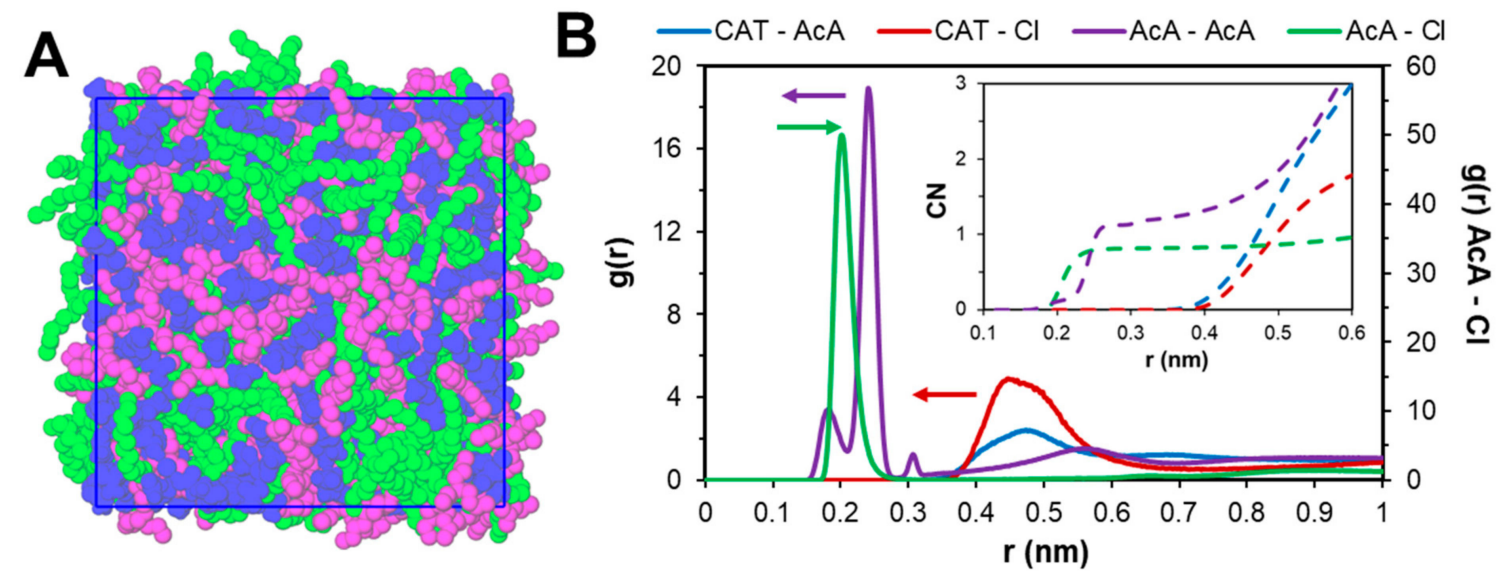

Figure 2. (A) Snapshot of the equilibrated $\left[\mathrm{P}_{44414}\right] \mathrm{Cl}+\mathrm{CH}_{3} \mathrm{COOH}$ system with chloride anion and acetic acid in blue and $\mathrm{C}_{4}$ and $\mathrm{C}_{14}$ alkyl chains of $\left[\mathrm{P}_{44414}\right]^{+}$in purple and green respectively. (B) Radial distribution functions (RDFs) of the principal intermolecular interactions. The reference atom for $\left[\mathrm{P}_{44414}\right]^{+}(\mathrm{CAT})$ was $\mathrm{P}$ whilst $\mathrm{OH}$ was taken for the carboxylic acid (AcA).

Upon addition of water, all intermolecular interactions identified in the pure mixture are systematically weakened, consistent with reported experimental and modeling of the influence of water on hydrophilic DES $[33,52,53]$. The systematic weakening of intermolecular interactions as each component becomes solvated is non-linear as exemplified in the $\mathrm{CH}_{3} \mathrm{COOH} \cdots \mathrm{Cl}^{-} \mathrm{RDF}$ and resulting coordination number $(\mathrm{CN})$ with increasing water content in Figure $3 \mathrm{~A}, \mathrm{~B}$. The defining interactions in the anhydrous mixture rapidly decrease with an increase in the water concentration and practically disappear as the system becomes sufficiently diluted. A clear break in the $\mathrm{CH}_{3} \mathrm{COOH} \cdot \mathrm{Cl}^{-}$ $\mathrm{CN}$ is observed at approximately $18.0 \mathrm{wt} . \% \mathrm{H}_{2} \mathrm{O}$, Figure $3 \mathrm{~B}$, with such behavior attributed to the change in system nanostructure from "water-in-IL" to "IL-in-water". Under "water-in-IL" conditions for the $\left[\mathrm{P}_{44414}\right] \mathrm{Cl}+\mathrm{CH}_{3} \mathrm{COOH}$ system $\left(\left[\mathrm{H}_{2} \mathrm{O}\right] \leq 15.0\right.$ wt. $\left.\%\right)$, gradual hydration of the system polar component 
is observed in which water molecules replace acetic acid and $\left[\mathrm{P}_{44414}\right]^{+}$around chloride anions forming hydrogen-bonded hydrated clusters as shown in Figure 3C. This shift in the molecular-scale segregation is also reflected in the $\mathrm{CH}_{3} \mathrm{COOH} \cdots \mathrm{Cl}^{-}$domain analysis in Figure S2, calculated based on the Voronoi tessellation method [54,55], which indicates a systematic non-linear increase in the subset dispersivity upon water addition presenting a similar trend discontinuity as in Figure 3B. Relative to chloride anions, a significant fraction of the dispersive interaction between $\mathrm{CH}_{3} \mathrm{COOH}$ and $\left[\mathrm{P}_{44414}\right]^{+}$is maintained even at high water content, Figure S3. This is further evidenced in the 3D spatial density function (SDF) plots in Figure 3D projecting the most likely configurations of the various system components around acetic acid for three water concentrations. Whilst acetic acid-chloride (blue surface) hydrogen bonding is weakened due to intercalation of water (overlapping cyan surface), the presence of $\left[\mathrm{P}_{44414}\right]^{+}$ (yellow surface) around acetic acid is maintained even under dilute conditions.
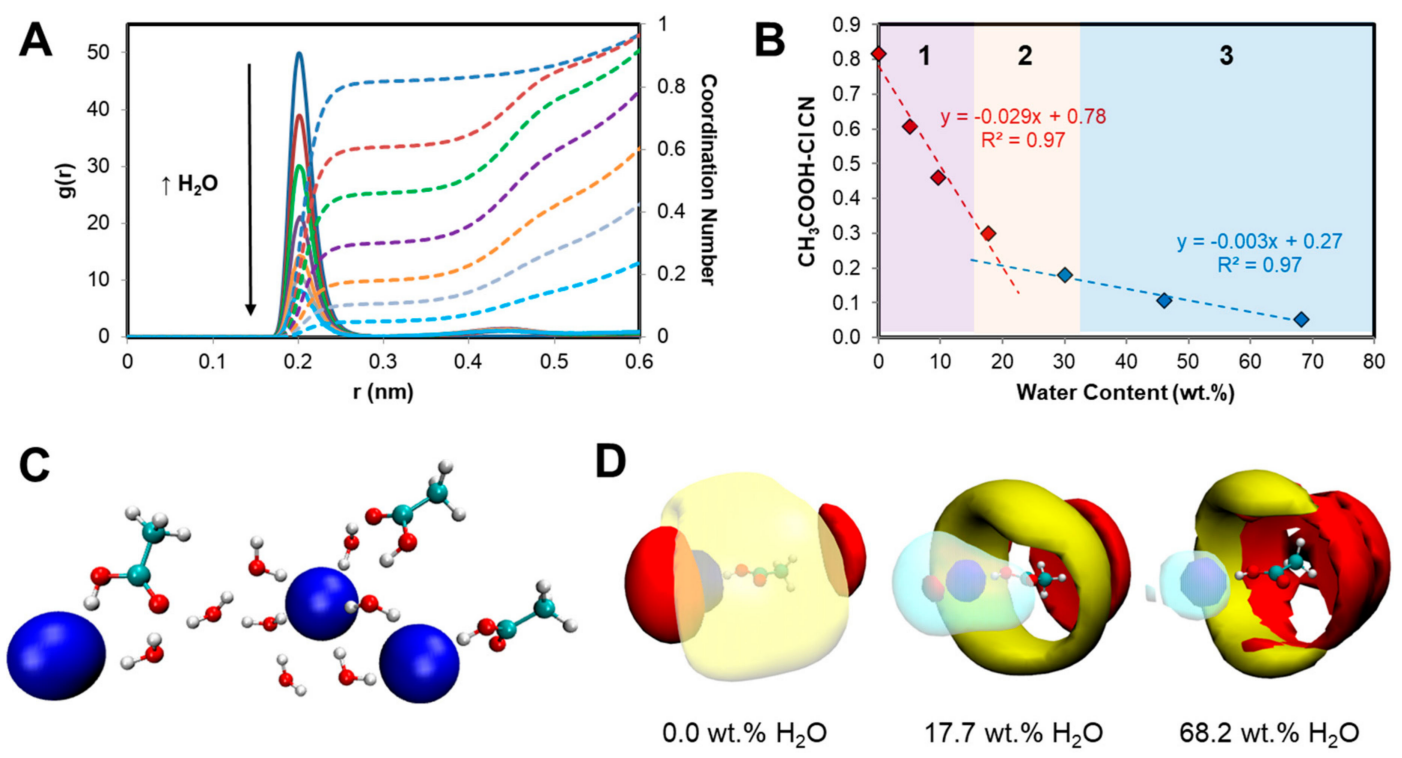

Figure 3. (A) $\mathrm{RDFs}$ of the $\mathrm{CH}_{3} \mathrm{COOH} \cdots \mathrm{Cl}^{-}$with increasing water content (reference atoms for acetic acid were $\mathrm{OH}$ ) and (B) corresponding coordination numbers (region 1 and 3 are monophasic whilst region 2 corresponds to the experimentally determined biphasic regime). (C) A representative snapshot of water-in-IL hydrated clusters for $5.1 \mathrm{wt} . \% \mathrm{H}_{2} \mathrm{O}$. (D) Spatial density function plots of the various system components around acetic acid for three water concentrations $\left(\mathrm{Cl}^{-}\right.$-blue; $\left[\mathrm{P}_{44414}\right]^{+}$-yellow; $\mathrm{CH}_{3} \mathrm{COOH}-$ red; $\mathrm{H}_{2} \mathrm{O}-$ cyan).

Interestingly, the observed discontinuity in Figure 3B or Figure S2 at approximately 18.0 wt.\% coincides with the start of the experimentally determined biphasic regime. Such a trend points to the unequal "washing-out" and resulting solvophobic segregation of the components upon dilution, resulting in the phase separation of the system into a more apolar $\left[\mathrm{P}_{44414}\right] \mathrm{Cl}$ bi-continuous phase stabilized by adsorbed organic acid molecules and a water-rich phase. Further addition of water results in the complete solubilization of all components and the return of the monophasic system containing a $\left[\mathrm{P}_{44414}\right] \mathrm{Cl}$ micellar phase ( $\leq 40.0 \mathrm{wt}$.\% IL) [38]. The presence of adsorbed neutral acetic acid onto the $\left[\mathrm{P}_{44414}\right] \mathrm{Cl}$ aggregate through acid alkyl moiety, shown in Figure S1, increases the dehydration of the aggregate surface and favors aggregate coalescence. Dynamic light scattering (DLS) analysis of $\left[\mathrm{P}_{44414}\right]^{+}$ micelles (20.0 wt.\% IL) in the presence of acetic acid, presented in Figure S4, shows the minimal micelle swelling with increasing acid concentration. This suggests that coacervation occurs rather through the nearing of neighboring micelles into a bi-continuous regime rather than through micelle-micelle fusion.

\subsection{Metal Oxide Leaching in the $\left[\mathrm{P}_{44414}\right] \mathrm{Cl}+\mathrm{CH}_{3} \mathrm{COOH}$ System}

Having characterized its phase diagram and addressed the underlying mechanism of phase separation, the solubility of metal oxide in the $\left[\mathrm{P}_{44414}\right] \mathrm{Cl}+\mathrm{CH}_{3} \mathrm{COOH}$ system is investigated. 
The solubility of three transition metal oxides $\mathrm{CoO}, \mathrm{NiO}, \mathrm{Fe}_{2} \mathrm{O}_{3}$ and one rare earth oxide $\mathrm{Nd}_{2} \mathrm{O}_{3}$ commonly found in nickel-metal hydride batteries (NiMH) in a $73.0 \mathrm{wt} . \%\left[\mathrm{P}_{44414}\right] \mathrm{Cl}$ and $27.0 \mathrm{wt} . \%$ $\mathrm{CH}_{3} \mathrm{COOH}$ mixture at $323 \mathrm{~K}$ for $24 \mathrm{~h}$ is presented in Table 3 . The mixture composition was selected such that a biphasic system could be obtained through the addition of water after metal oxide dissolution, with a 2.7 molar excess of acetic acid relative to the IL. At this composition, the mixture presents a moderate viscosity of $106.7 \mathrm{cP}$ at $293 \mathrm{~K}$ which decreases to a manageable $27.7 \mathrm{cP}$ at $323 \mathrm{~K}$ (Figure 4), an important consideration for the kinetics of mass transport during leaching. The water content of the "dry" mixture is of $1.3 \mathrm{wt} . \% \mathrm{H}_{2} \mathrm{O}$ as measured by Karl-Fisher.

Table 3. Gibbs energy of formation $\left(\Delta_{f} G^{o}\right)$ and solubility for selected metal oxides in $\left[\mathrm{P}_{44414}\right] \mathrm{Cl}+\mathrm{CH}_{3} \mathrm{COOH}$ after $24 \mathrm{hr}$ at $323 \mathrm{~K}$ compared to that in choline chloride $([\mathrm{Ch}] \mathrm{Cl}))+\mathrm{CH}_{3} \mathrm{COOH}(1: 2)$ DES.

\begin{tabular}{|c|c|c|c|}
\hline \multirow[b]{2}{*}{ Metal Oxide } & \multirow{2}{*}{$\Delta_{f} G^{o}\left(\mathrm{~kJ} \cdot \mathrm{mol}^{-1}\right)$} & Solubility $\left(\mathrm{mol} \cdot \mathrm{L}^{-1}\right)$ & Solubility $\left(\mathrm{mol} \cdot \mathrm{L}^{-1}\right)$ \\
\hline & & {$\left[\mathrm{P}_{44414}\right] \mathrm{Cl}+\mathrm{CH}_{3} \mathrm{COOH}$} & {$[\mathrm{Ch}] \mathrm{Cl}+\mathrm{CH}_{3} \mathrm{COOH}^{\mathrm{a}}$} \\
\hline $\mathrm{CoO}$ & $-214.1^{a}$ & $0.349 \pm 0.030$ & $\sim 0.10$ \\
\hline $\mathrm{NiO}$ & $-211.7^{a}$ & $0.028 \pm 0.001$ & $\sim 0.01$ \\
\hline $\mathrm{Fe}_{2} \mathrm{O}_{3}$ & $-742.8^{a}$ & $0.015 \pm 0.001$ & $<0.01$ \\
\hline $\mathrm{Nd}_{2} \mathrm{O}_{3}$ & $-1854.2^{b}$ & $0.036 \pm 0.002$ & - \\
\hline
\end{tabular}

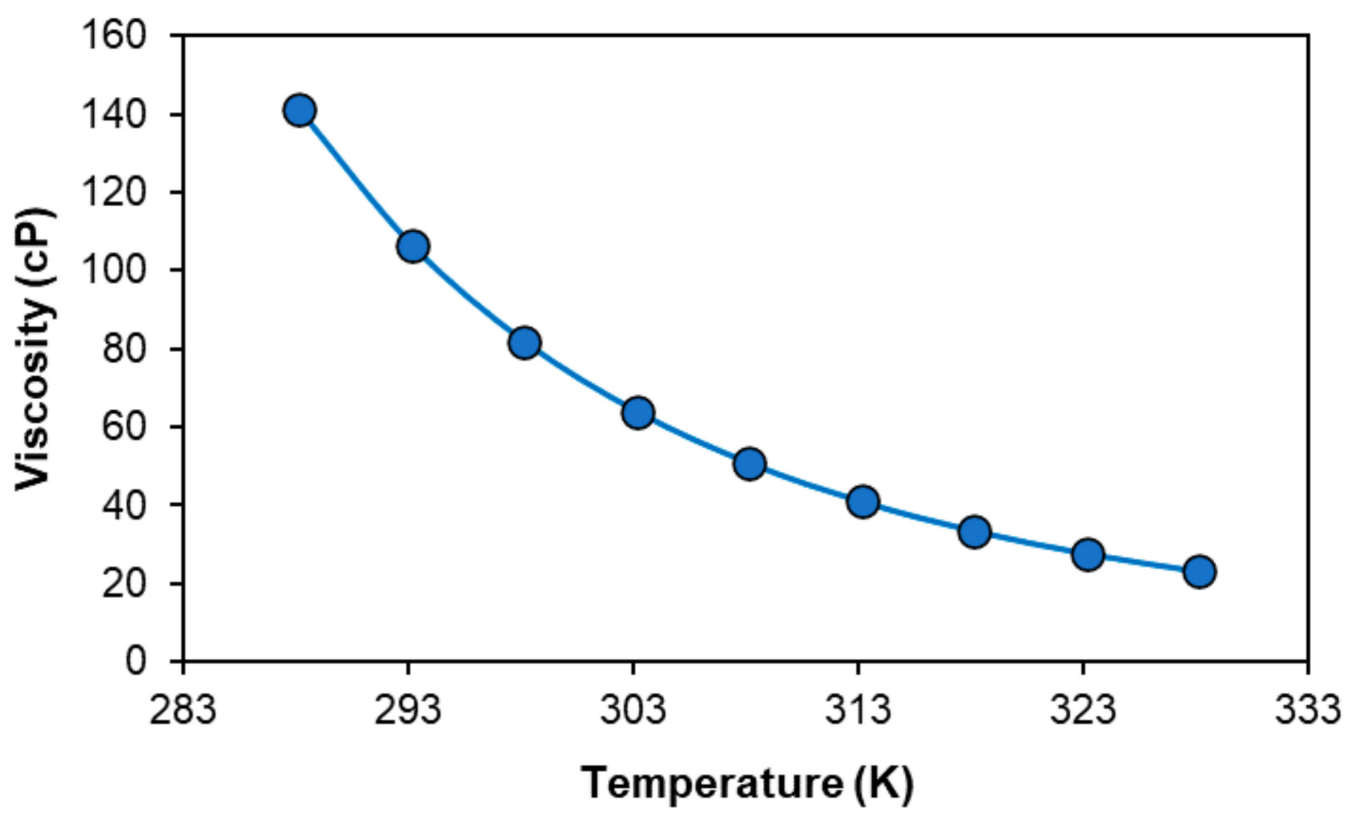

Figure 4. Viscosity of the 73.0 wt. $\%\left[\mathrm{P}_{44414}\right] \mathrm{Cl}$ and $27.0 \mathrm{wt} . \% \mathrm{CH}_{3} \mathrm{COOH}$ mixture as a function of temperature.

Total metal oxide solubility in the $\left[\mathrm{P}_{44414}\right] \mathrm{Cl}+\mathrm{CH}_{3} \mathrm{COOH}$ system proceeds as $\mathrm{CoO}>>\mathrm{Nd}_{2} \mathrm{O}_{3}$ $>\mathrm{NiO}>\mathrm{Fe}_{2} \mathrm{O}_{3}$. The observed transition metal oxide solubility trend in the $\left[\mathrm{P}_{44414}\right] \mathrm{Cl}+\mathrm{CH}_{3} \mathrm{COOH}$ mixture is consistent with that reported for choline chloride $([\mathrm{Ch}] \mathrm{Cl})+\mathrm{CH}_{3} \mathrm{COOH}$ DES as shown in Table 3. Interestingly, $\mathrm{CoO}$ presents a higher solubility in the $\left[\mathrm{P}_{44414}\right] \mathrm{Cl}+\mathrm{CH}_{3} \mathrm{COOH}$ system compared to that in the corresponding 1:2 $[\mathrm{Ch}] \mathrm{Cl}+\mathrm{CH}_{3} \mathrm{COOH}$ solvent despite the lower chloride concentration of $1.68 \mathrm{~mol} \mathrm{~kg}^{-1}$ compared to $3.82 \mathrm{~mol} \mathrm{~kg}^{-1}$ respectively [42]. This is attributed to the greater hydrogen-bonded network, and therefore greater viscosity in choline chloride-based mixtures compared to the more aliphatic character of the $\left[\mathrm{P}_{44414}\right] \mathrm{Cl}+\mathrm{CH}_{3} \mathrm{COOH}$ system. The presence of water in the mixture negatively influences the total $\mathrm{CoO}$ solubility. For a constant $\left[\mathrm{P}_{44414}\right] \mathrm{Cl}$ to $\mathrm{CH}_{3} \mathrm{COOH}$ molar ratio, the solubility of $\mathrm{CoO}$ slightly decreased from $0.349 \mathrm{~mol} \mathrm{~L}^{-1}$ in the "dry" 
mixture (containing 1.3 wt. $\% \mathrm{H}_{2} \mathrm{O}$ ) to $0.258 \mathrm{~mol} \mathrm{~L}^{-1}$ for a diluted mixture containing 30.0 wt.\% $\mathrm{H}_{2} \mathrm{O}$. This is most likely due to the increased solvation of the chloride anion limiting its chemisorption onto the active sites of the metal salt [42]. Despite the lower solubility of the transition metal oxides in the $\left[\mathrm{P}_{44414}\right] \mathrm{Cl}+\mathrm{CH}_{3} \mathrm{COOH}$ system compared to mixtures incorporating stronger acids such as oxalic, lactic, maleic or toluene sulfonic acid,[13,42,57] the studied system presents a moderate selectivity for CoO. Nevertheless, additional separation is required to obtain a final cobalt product of suitable purity.

Metal oxide solubility in mixtures of halogenated salts with Brønsted acids was shown to be dependent on its Gibbs energy of formation $\left(\Delta_{f} G^{o}\right)$, explaining the greater solubility of CoO compared to $\mathrm{Fe}_{2} \mathrm{O}_{3}$ (Table 3) [42]. However, such a justification does not explain the low solubility of $\mathrm{NiO}$ or the unexpectedly high solubility of $\mathrm{Nd}_{2} \mathrm{O}_{3}$, the most stable of the tested oxides. Although the $\Delta_{f} G^{o}$ values of $\mathrm{NiO}$ and $\mathrm{CoO}$ are similar, the significantly greater solubility of $\mathrm{CoO}$ in the $\left[\mathrm{P}_{44414}\right] \mathrm{Cl}+\mathrm{CH}_{3} \mathrm{COOH}$ mixture is assigned to the more chlorophilic nature of $\mathrm{Co}(\mathrm{II})$ compared to $\mathrm{Ni}(\mathrm{II})$. This is evidenced when comparing the UV-vis spectra of the metal oxide saturated $\left[\mathrm{P}_{44414}\right] \mathrm{Cl}+\mathrm{CH}_{3} \mathrm{COOH}$ solution to the corresponding spectra of the salt in water, Figure 5 . The $\mathrm{CoO}$ saturated $\left[\mathrm{P}_{44414}\right] \mathrm{Cl}+\mathrm{CH}_{3} \mathrm{COOH}$ solution displayed a deep blue color characteristic of the tetrahedral $\mathrm{CoCl}_{4}{ }^{2-}$ complex. Similarly, the UV-vis spectrum of Fe(III) in aqueous solution differs from that in the IL mixture after leaching, with the latter indicating the existence of $\mathrm{Fe}(\mathrm{III})$ as the $\mathrm{FeCl}_{4}{ }^{-}$specie [58]. Whilst most transition metals form tetrachloride species in chloride-containing ionic solvents and mixtures, the speciation of nickel was found to differ [5]. Qualitative comparison of the spectrum of Ni(II) in water and in the $\left[\mathrm{P}_{44414}\right] \mathrm{Cl}+\mathrm{CH}_{3} \mathrm{COOH}$ mixture after leaching confirms the stability of the $\mathrm{Ni}$ (II) octahedral geometry. The absorption bands of aqueous $\left[\mathrm{Ni}\left(\mathrm{H}_{2} \mathrm{O}\right)_{6}\right]^{2+}$ at $395 \mathrm{~nm}$ and $720 \mathrm{~nm}$ are blue-shifted to $365 \mathrm{~nm}$ and $705 \mathrm{~nm}$ respectively, whilst the relative absorption of the band at $365 \mathrm{~nm}\left({ }^{3} \mathrm{~A}_{2 \mathrm{~g}} \rightarrow{ }^{3} \mathrm{~T}_{1 \mathrm{~g}}(\mathrm{P})\right.$ transition) decreases in the mixture and a new shoulder appears at $615 \mathrm{~nm}$. The UV-vis spectrum of $\mathrm{Ni}(\mathrm{II})$ in the mixture are inconsistent with that of $\mathrm{Ni}(\mathrm{II})$ in concentrated chloride solutions in which a systematic red-shift of the bands is observed as chloride progressively replaces $\mathrm{H}_{2} \mathrm{O}$ within the first coordination shell [59]. These differences confirm the more complex Ni(II) coordination in the $\left[\mathrm{P}_{44414}\right] \mathrm{Cl}+\mathrm{CH}_{3} \mathrm{COOH}$ mixture and its probable interaction with neutral acetic acid. ILs incorporating carboxylic acid moieties as well as mixtures containing carboxylic acids, such as ethylene glycol + maleic acid, were shown to efficiently solubilize rare earth oxides despite the latter's stability $\left(\Delta_{f} G^{o}\left(\mathrm{Nd}_{2} \mathrm{O}_{3}\right)=-1854.2 \mathrm{~kJ} \mathrm{~mol}^{-1}\right)[57,60,61]$. In such solutions, a small amount of water was proven to enhance the oxide solubility by facilitating the acid deprotonation $[60,61]$. The water content of $1.3 \mathrm{wt} \%$ $\mathrm{H}_{2} \mathrm{O}$ in the $\left[\mathrm{P}_{44414}\right] \mathrm{Cl}+\mathrm{CH}_{3} \mathrm{COOH}$ mixture could partially explain the observed $\mathrm{Nd}_{2} \mathrm{O}_{3}$ solubility. The UV-vis spectrum for $\mathrm{Nd}(\mathrm{III})$ in Figure 5 is characterized by a number of Laporte-forbidden $\mathrm{f}-\mathrm{f}$ transitions, with the spectrum of $\mathrm{Nd}$ (III) in the mixture red-shifted relative to its aqueous spectrum suggesting that $\mathrm{Nd}(\mathrm{III})$ is complexed with acetate anions. This appears as the likeliest scenario considering the far greater complexation constant of neodymium with acetate compared to chloride ligands $[62,63]$. 

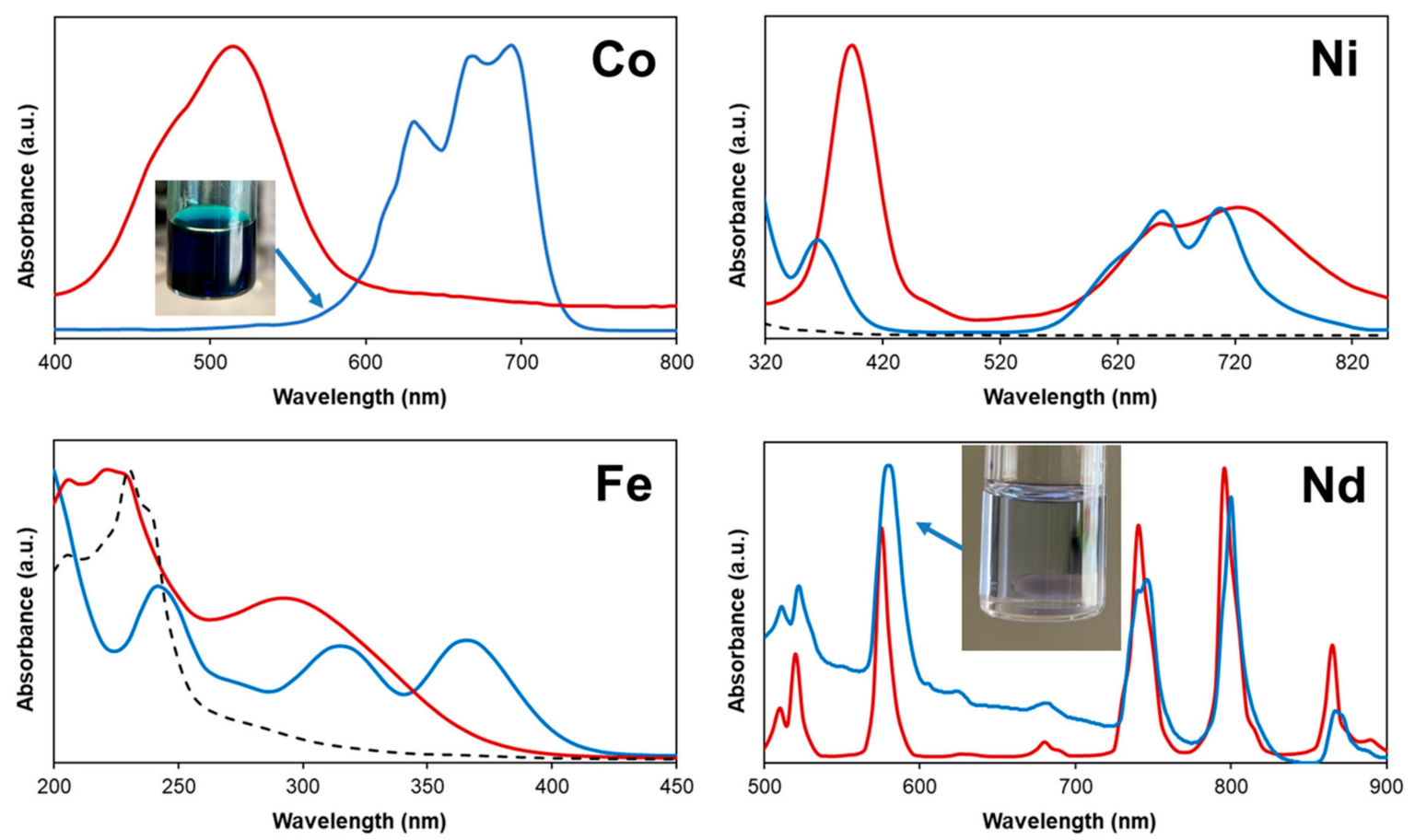

Figure 5. UV-vis spectra of the $\left[\mathrm{P}_{44414}\right] \mathrm{Cl}+\mathrm{CH}_{3} \mathrm{COOH}$ system $\left(73.0\right.$ wt.\% $\left[\mathrm{P}_{44414}\right] \mathrm{Cl}$ and 27.0 wt.\% $\mathrm{CH}_{3} \mathrm{COOH}$ ) after metal oxide dissolution at $323 \mathrm{~K}$ for $24 \mathrm{~h}$ (blue line) and the corresponding spectra of the metal chloride salt in aqueous solution (red line). The dashed line corresponds to the spectra of the $\left[\mathrm{P}_{44414}\right] \mathrm{Cl}+\mathrm{CH}_{3} \mathrm{COOH}$ mixture in the absence of metals.

\subsection{Application of the $\left[\mathrm{P}_{44414}\right] \mathrm{Cl}+\mathrm{CH}_{3} \mathrm{COOH}$ System to Waste NiMH Battery}

Based on the results presented above the $\left[\mathrm{P}_{44414}\right] \mathrm{Cl}+\mathrm{CH}_{3} \mathrm{COOH}$ system is applied in the integrated process of leaching and separation of $\mathrm{Co}$ (II) from real waste NiMH battery black mass obtained from an industrial recycler (Recupyl, Grenoble, France). NiMH battery black mass is characterized by a high $\mathrm{Ni}(\mathrm{II})$ concentration, as well as lesser quantities of rare earth elements, $\mathrm{Co}(\mathrm{II}), \mathrm{Mn}$ (II) and $\mathrm{Zn}$ (II). Impurities such as Fe(III) are often also encountered [64]. To minimize acid-base neutralization from residual $\mathrm{KOH}$ battery electrolyte, the black mass was rinsed with deionized water until a stable $\mathrm{pH}$ was obtained prior to leaching studies. Two systems were evaluated for the leaching of $\mathrm{Co}$ (II) from the complex waste matrix: (i) an aqueous solution of $27.0 \mathrm{wt} . \% \mathrm{CH}_{3} \mathrm{COOH}$, (ii) $73.0 \mathrm{wt} . \%$ $\left[\mathrm{P}_{44414}\right] \mathrm{Cl}+27.0 \mathrm{wt} . \% \mathrm{CH}_{3} \mathrm{COOH}$. $\mathrm{Co}$ (II) leaching in the $\left[\mathrm{P}_{44414}\right] \mathrm{Cl}+\mathrm{CH}_{3} \mathrm{COOH}$ mixture is comparable to that using an aqueous acetic acid solution but present a greater selectivity, with a lower $\mathrm{Ni}(\mathrm{II})$, $\mathrm{Mn}$ (II) and rare earth element concentration, as shown in Figure 6A. However, an increase in Fe(III) and $\mathrm{Zn}$ (II) leaching is observed due to the higher chloride concentration resulting from the lower water content. 

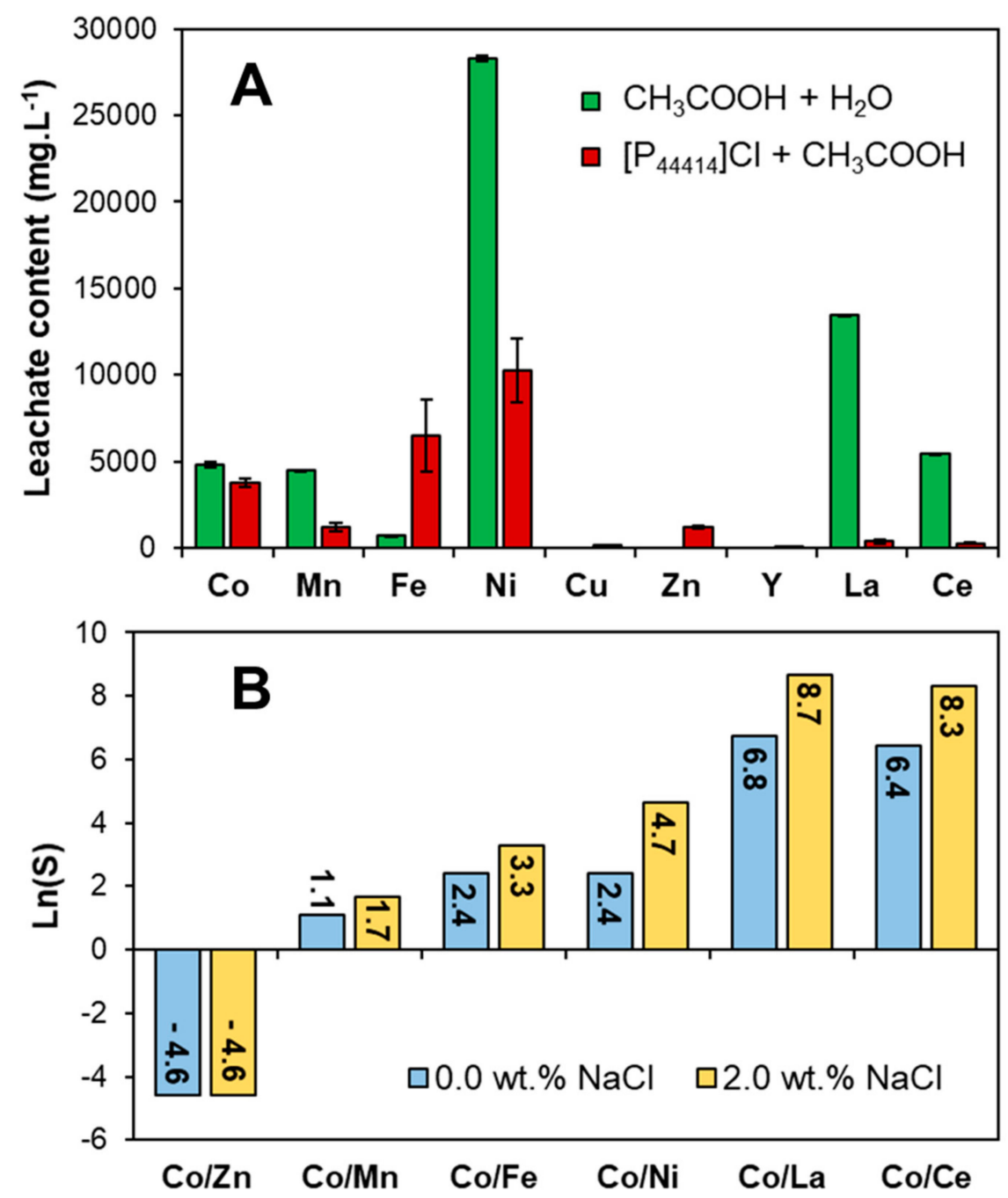

Figure 6. (A) Metal concentration in the NiMH battery leachate composed of $27.0 \mathrm{wt} . \% \mathrm{CH} 3 \mathrm{COOH}$ aqueous solution and in the $73.0 \mathrm{wt} . \%\left[\mathrm{P}_{44414}\right] \mathrm{Cl}+27.0 \mathrm{wt} . \% \mathrm{CH}_{3} \mathrm{COOH}$ mixture $(\mathrm{t}=24 \mathrm{~h}, \mathrm{~T}=323 \mathrm{~K}$, $\mathrm{S} / \mathrm{L}=0.1$ ). (B) $\mathrm{Co}(\mathrm{II})$ selectivity $(\mathrm{S})$ in the biphasic $\left[\mathrm{P}_{44414}\right] \mathrm{Cl}+\mathrm{CH}_{3} \mathrm{COOH}+\mathrm{H}_{2} \mathrm{O}$ from the principal metals in the NiMH leachate. The total composition of systems 1 and $1^{*}$ are provided in Table 1; individual metal distribution coefficients are available in Table S1.

Following the leaching of the black mass for $24 \mathrm{~h}$ at $323 \mathrm{~K}$, the saturated $\left[\mathrm{P}_{44414}\right] \mathrm{Cl}+\mathrm{CH}_{3} \mathrm{COOH}$ mixture was diluted either with water or a $2.0 \mathrm{wt} . \% \mathrm{NaCl}$ until a biphasic system was obtained with composition $\mathbf{1}$ and $\mathbf{1}^{*}$ in Table 1 respectively. The distribution ratio (D) for a given metal $\mathrm{M}^{\mathrm{n}+}$ between both system phases is defined in Equation (1), whilst the system selectivity (S) for Co(II) is defined according to Equation (2):

$$
\begin{gathered}
\mathrm{D}_{\mathrm{M}}=\frac{\left[\mathrm{M}^{\mathrm{n}+}\right]_{\mathrm{IL}}}{\left[\mathrm{M}^{\mathrm{n}+}\right]_{\mathrm{H}_{2} \mathrm{O}}} \\
\mathrm{S}_{\frac{\mathrm{Co}_{\mathrm{O}}}{\mathrm{M}}}=\frac{\mathrm{D}_{\mathrm{Co}}}{\mathrm{D}_{\mathrm{M}}},
\end{gathered}
$$

where the subscript IL and $\mathrm{H}_{2} \mathrm{O}$ indicate the respective IL-rich and water-rich phases and $\left[\mathrm{M}^{\mathrm{n}+}\right]$ is the concentration of metal $\mathrm{M}^{\mathrm{n}+}$. The distribution coefficients and extraction percentages obtained in system 1 and $1^{*}$ are presented in Table S1 whilst the Co(II) selectivity is shown in Figure 6B. The addition of $2.0 \mathrm{wt} . \% \mathrm{NaCl}$ improves both the $\mathrm{Co}(\mathrm{II})$ partition to the IL-rich phase, increasing $\mathrm{D}_{\mathrm{Co}}$ from 0.10 to 0.49 , as well as the system selectivity (Figure $6 \mathrm{~B}$ ). Although the $\left[\mathrm{P}_{44414}\right] \mathrm{Cl}+\mathrm{CH}_{3} \mathrm{COOH}$ system presents 
a limited $\mathrm{D}_{\mathrm{Co}}$, this can be further improved through the addition of chloride salts to promote the formation of the anionic chlorocobalt complex. Optimal Co(II) extraction by phosphonium-based ILs occurs at around 6.0 to $8.0 \mathrm{~mol} \mathrm{~L}^{-1}$ of chloride, far above that in the studied system [65-67]. Addition of chloride salts presents the added benefit of (i) increasing the partition of $\mathrm{CH}_{3} \mathrm{COOH}$ to the IL-rich phase ( $c f$. Table 1) and (ii) extending the system biphasic region [65].

According to the results in Figure $6 \mathrm{~B}$ as well as the UV-vis spectra in Figure 5, metal partition in the $\left[\mathrm{P}_{44414}\right] \mathrm{Cl}+\mathrm{CH}_{3} \mathrm{COOH}$ biphasic system relies on the formation of neutral or anionic chlorometallate complexes and their subsequent extraction to the IL-rich phase via an ion-pairing or anion-exchange mechanism. Metal cations known not to form the required anionic complexes with chloride ligands such as $\mathrm{Ni}(\mathrm{II})$ and the lanthanides $\mathrm{La}(\mathrm{III})$ and $\mathrm{Ce}(\mathrm{III})$ are not extracted, resulting in a high $\mathrm{Co}(\mathrm{II})$ selectivity relative to these metals, Figure 6B. Conversely, the system presents moderate to no selectivity for $\mathrm{Co}(\mathrm{II})$ against the metals $\mathrm{Zn}$ (II), $\mathrm{Cu}$ (II) and $\mathrm{Mn}$ (II) as these form anionic complexes at lower ( $\mathrm{Zn}$ (II) and $\mathrm{Cu}(\mathrm{II}))$ or similar (Mn(II)) chloride concentrations as $\mathrm{Co}(\mathrm{II})$ [65-67]. Overall, a similar $\mathrm{Co}(\mathrm{II})$ selectivity trend is observed in the $\left[\mathrm{P}_{44414}\right] \mathrm{Cl}+\mathrm{CH}_{3} \mathrm{COOH}$ system compared to solvent-extraction using quaternary ammonium or phosphonium extractant with the notable extraction of Fe(III) [65-67]. In contrast to the preferential extraction of $\mathrm{Fe}(\mathrm{III})$ over $\mathrm{Co}(\mathrm{II})$ by the hydrophobic $\left[\mathrm{P}_{66614}\right] \mathrm{Cl}$ from chloride media, the $\left[\mathrm{P}_{44414}\right] \mathrm{Cl}+\mathrm{CH}_{3} \mathrm{COOH}$ presents an interesting selectivity towards $\mathrm{Co}$ (II) with $\mathrm{S}_{\mathrm{Co} / \mathrm{Fe}}=27.1$ most likely due to the competing complexation of acetic acid with chloride ligands. The $\left[\mathrm{P}_{44414}\right] \mathrm{Cl}+\mathrm{CH}_{3} \mathrm{COOH}$ system can selectively recover $\mathrm{Co}(\mathrm{II})$ from $\mathrm{Ni}(\mathrm{II}), \mathrm{Fe}(\mathrm{III})$ and the lanthanides from a complex waste matrix. $\mathrm{Co}(\mathrm{II})$ was enriched from $15.5 \mathrm{wt} . \%$ of the total metal content in the initial leachate to $54.7 \%$ in the IL-rich phase after phase separation through water addition. Zn(II) was the major impurity in the IL-rich phase, accounting for $23.6 \%$ of the extracted metal content.

Although some issues still need to be overcome to increase the applicability of the proposed system, namely the low $\mathrm{Co}(\mathrm{II})$ distribution and the cost and toxicity of $\left[\mathrm{P}_{44414}\right] \mathrm{Cl} \mathrm{IL}$, this work provides guidelines for the development of responsive non-aqueous mixtures for the integrated leaching and separation of critical metals from complex waste streams. The close to fourfold concentration of $\mathrm{Co}(\mathrm{II})$ in the mixture through the simple addition of water greatly simplifies downstream purification, opening the possibility for $\mathrm{Co}$ (II) recovery by electrodeposition [65]. This proof of concept demonstrates how the judicious mixture of an IL with an organic acid can result in the selective "one-pot" leaching and solvent extraction separation of target metals from multiple impurities present in a real waste matrix through the simple addition of water as a counter-solvent. This contrasts with leaching processes using aqueous acidic solutions or hydrophilic eutectic solvents from which additional separation stages requiring further solvent consumption are required.

\section{Methodology}

\subsection{Reagent and Instrumentation}

The ionic liquids $\left[\mathrm{P}_{4444}\right] \mathrm{Cl}(95.0 \mathrm{wt} . \%),\left[\mathrm{P}_{44414}\right] \mathrm{Cl}(95.0 \mathrm{wt} . \%)$ were obtained from Cytec industries, $\left[\mathrm{N}_{4444}\right] \mathrm{Cl}(97.0 \mathrm{wt} . \%)$ from Sigma-Aldrich (St. Louis, MO, USA)and [C $\left.{ }_{14} \mathrm{mim}\right] \mathrm{Cl}(98.0 \mathrm{wt} . \%)$ from Iolitec (Heilbronn, Germany). Citric acid (99.5 wt.\%) was obtained from Panreac, lactic acid (92.0 wt.\%) from Riedel de Haen and acetic acid (99.9 wt.\%) from Fisher Scientific (Waltham, MA, USA). Neodymium (III) oxide (99.99\%), cobalt (II) oxide (95\%) and iron (III) oxide (98\%) were purchased from Alfa Aesar (Haverhill, MA, USA) whilst nickel (II) oxide (99.99\%) and the gallium standard (1000 $\mathrm{mg} \mathrm{L}^{-1}$ ) were acquired from Sigma-Aldrich. Ammonium acetate ( $98.0 \mathrm{wt} . \%$ ) and sodium chloride (99.5 wt.\%) were obtained from Merck (Darmstadt, Germany) and and Fisher Scientific, respectively. All chemicals were used as received. Ultrapure deionized water was used in all experiments and obtained from an ultra-filtration system by reverse osmosis and subsequently passed through a Milli-Q plus 185 water purification apparatus ( $18.2 \mathrm{M} \Omega \mathrm{cm}$ to $298 \mathrm{~K})$. All systems were gravimetrically prepared through careful weighing of each component using an analytical scale (Precisa gravimetries AG, uncertainty $0.0001 \mathrm{~g}$ ). The cation of the ionic liquid $\left(\left[\mathrm{P}_{44414}\right]^{+}\right)$was quantified by ${ }^{1} \mathrm{H}-\mathrm{NMR}$ (Bruker Avance III, 
$400 \mathrm{~Hz}$ (Billerica, MA, USA)) using as internal standard a benzene probe of known concentration. Acid-base titration was used to determine acid contraction in the phases (Titroline $6000 \mathrm{pH}$ meter; $0.1 \%$ ). Karl Fischer titration was used to determine the amount of water (Titroline $7500 \mathrm{KF}$ Trace; $0.15 \%$ ). A thermostatic bath (ME-18 V Visco-Thermostat, Julabo, (Seelbach, Germany) $\pm 0.1 \mathrm{~K}$ ) was used for temperature control. Viscosity was determined using a viscometer-densimeter SVM 3000 Anton Paar Rotary Stabinger (Graz, Austria), with a temperature uncertainty of $\pm 0.1 \mathrm{~K}$ and a relative uncertainty of dynamic viscosity of $\pm 0.35 \%$. Aggregate size measurements were made by dynamic light scattering (DLS) (Malvern Zetasizer Nano-ZS) measurements. For measurements of metals has been used Picofox S2 (Bruker Nano (Billerica, MA, USA)) total reflection X-ray fluorescence spectrometer with a molybdenum $X$-ray source. The voltage of the $X$-ray tube was $50 \mathrm{kV}$ and the current $600 \mu \mathrm{A}$. All carriers were first pretreated with $10 \mu \mathrm{L}$ of silicon in isopropanol solution and dried at $353 \mathrm{~K}$ for $30 \mathrm{~min}$. Ten microliters of each solution containing the metals and standard of Ga were added onto a clean carrier and dried on a hot plate at $60^{\circ} \mathrm{C}$ for $15 \mathrm{~min}$.

\subsection{Determination and Characterisation of $\left[\mathrm{P}_{44414}\right] \mathrm{Cl}+$ Organic Acid $+\mathrm{H}_{2} \mathrm{O}$ Systems}

In a first instance, a screening of four different ILs, namely $\left[\mathrm{N}_{4444}\right] \mathrm{Cl},\left[\mathrm{P}_{4444}\right] \mathrm{Cl},\left[\mathrm{P}_{44414}\right] \mathrm{Cl}$ and $\left[\mathrm{C}_{14} \mathrm{mim}\right] \mathrm{Cl}$, with various water-soluble organic acids in aqueous solutions was performed at $323 \mathrm{~K}$ to identify potential biphasic mixtures. For each $\mathrm{IL}+$ organic acid $+\mathrm{H}_{2} \mathrm{O}$ system, two initial binary mixture compositions were selected to which the third component was titrated until the system became turbid. Initial mixture compositions were of 75.0 wt.\% IL in water and a 50:50 wt.\% IL + organic acid (including the initial acid water content), respectively.

Based on the screening results, the phase diagram of the $\left[\mathrm{P}_{44414}\right] \mathrm{Cl}+\mathrm{CH}_{3} \mathrm{COOH}+\mathrm{H}_{2} \mathrm{O}$ system was experimentally determined using a combination of the cloud point titration method and turbidimetric method performed in a temperature-controlled thermostatic bath. The cloud point, representing the solution turbidity caused by phase demixing, was visually detected when a mass of acid or aqueous salt solution was added dropwise over an aqueous IL solution of known mass, and a known mass of water was added until the solution became clear again, this process being repeated several times. The $\left[\mathrm{P}_{44414}\right] \mathrm{Cl}$ and $\mathrm{CH}_{3} \mathrm{COOH}$ concentration ranges probed in this study are 2.0 to $75.0 \mathrm{wt}$. \% IL and 0.0 to 30.0 wt. \% $\mathrm{CH}_{3} \mathrm{COOH}$ respectively. Additionally, to delimit the "type 0 " phase diagram of $\left[\mathrm{P}_{44414}\right] \mathrm{Cl}+\mathrm{CH}_{3} \mathrm{COOH}+\mathrm{H}_{2} \mathrm{O}$, mixing points of known composition concentrated in organic acid and IL were prepared and a known mass of water was added dropwise in each tube until the appearance of cloudiness. All mixing points were made in triplicate.

The composition of the equilibrium phases for selected mixture points at $323 \mathrm{~K}$ was experimentally determined. The mixtures were gravimetrically prepared, agitated and left to separate for $12 \mathrm{~h}$ under temperature control. The equilibrium phases were carefully separated to determine the respective concentration of IL, $\mathrm{CH}_{3} \mathrm{COOH}$ and water in each phase. All mixing points were made in duplicate. DLS measurements were performed to evaluate the variation in $\left[\mathrm{P}_{44414}\right]^{+}$aggregate size as a function of $\mathrm{CH}_{3} \mathrm{COOH}$ concentration. A constant $\left[\mathrm{P}_{44414}\right] \mathrm{Cl}$ concentration of $20.0 \mathrm{wt}$. \% was used in all DLS measurements, corresponding to the micellar regime of this surfactant [38]. Samples were irradiated with a HeNe laser $(\lambda=565 \mathrm{~nm})$ and the intensity fluctuations of the scattered light were detected at a backscattering angle of $173^{\circ}$ to generate an autocorrelation function. The autocorrelation function was corrected from the default settings for deionized water by adjusting for the solution viscosity $(3.586 \mathrm{cP})$ and refractive index (1.3324). The cumulant analysis of this function provided by the software DTS $\mathrm{v}$ 7.03 yielded the particle size and the distribution width. Each composition tested was analyzed three times to ensure the formation of stable aggregates. Ultrapure water was used in all analyses.

\subsection{Dissolution of Metal Oxides and Separation}

The solubilities of different transition metal and rare earth oxides $\left(\mathrm{NiO}, \mathrm{CoO}, \mathrm{Fe}_{2} \mathrm{O}_{3}, \mathrm{Nd}_{2} \mathrm{O}_{3}\right)$ in the $\left[\mathrm{P}_{44414}\right] \mathrm{Cl}+\mathrm{CH}_{3} \mathrm{COOH}$ (73.0 wt.\% IL, 27.0 wt.\% $\mathrm{CH}_{3} \mathrm{COOH}$ ) system were experimentally determined through the addition of an excess of metal oxide to $2.0 \mathrm{~g}$ the mixture for $24 \mathrm{~h}$ at $323 \mathrm{~K}$ and $500 \mathrm{rpm}$. 
The leachate was subsequently isolated by centrifugation and appropriately diluted using deionized water prior to metal concentration analysis by UV-vis and TXRF.

The system $\left[\mathrm{P}_{44414}\right] \mathrm{Cl}+\mathrm{CH}_{3} \mathrm{COOH}\left(73.0 \mathrm{wt} . \% \mathrm{IL}, 27.0 \mathrm{wt} . \% \mathrm{CH}_{3} \mathrm{COOH}\right)$ was subsequently used to leach and separate the metals contained in the real waste NiMH battery black mass. NiMH battery black mass was kindly provided by an industrial recycler (Recupyl, Grenoble, France) and washed with deionized water prior to use to remove residual $\mathrm{KOH}$ electrolyte. To $1.8 \mathrm{~g}$ of the IL + acid mixture was added $0.18 \mathrm{~g}$ of waste NiMH black mass and left under stirring at $500 \mathrm{rpm}$ for $24 \mathrm{~h}$ at $323 \mathrm{~K}$. Following leaching, the saturated $\left[\mathrm{P}_{44414}\right] \mathrm{Cl}+\mathrm{CH}_{3} \mathrm{COOH}$ mixture was diluted with $0.5 \mathrm{~g}$ of $\mathrm{H}_{2} \mathrm{O}$ or a $2.0 \mathrm{wt} . \%$ aqueous $\mathrm{NaCl}$ solution until a biphasic system was obtained. The systems were centrifugated to speed up the phase separation. The phases were subsequently diluted using deionized water prior to metal concentration analysis by UV-vis and TXRF. The same leaching conditions, namely $500 \mathrm{rpm}$ for $24 \mathrm{~h}$ at $323 \mathrm{~K}$ and a solid-to-liquid ratio of 0.1 , were employed to evaluate the leaching of metals from $0.18 \mathrm{~g}$ of the black mass using an aqueous solution of $27.0 \mathrm{wt} . \% \mathrm{CH}_{3} \mathrm{COOH}$.

\subsection{Molecular Dynamic Simulations of the $\left[\mathrm{P}_{44414}\right] \mathrm{Cl}+\mathrm{CH}_{3} \mathrm{COOH}+\mathrm{H}_{2} \mathrm{O}$ System}

All simulations were carried out with the Gromacs 5.1 package [68] within the NpT ensemble by adopting the leapfrog algorithm to integrate the equations of motion with a time step of $2 \mathrm{fs}$ at a fixed temperature ( $323 \mathrm{~K}$ ) and pressure (1 bar) [69]. The energy contributions in the potential energy function for bonded interactions were bond stretching, angle bending and dihedral torsion, whilst non-bonded inter-actions were modelled by Lennard-Jones (LJ) and Coulombic terms. The force-switch van der Waals potential modifier was employed for LJ, where the energy decays smoothly to zero between 0.9 and $1.2 \mathrm{~nm}$, while long-range Coulombic interactions were evaluated by particlemesh Ewald (PME) [70], up to a cut-off radius of $1.2 \mathrm{~nm}$. The temperature and pressure were fixed at $323 \mathrm{~K}$ and 1 bar through the Nose-Hoover thermostat [71] and the Parrinello-Rahman barostat [72], respectively. All bonds were constrained by the LINCS algorithm during the simulations [73]. The force field parameters for $\left[\mathrm{P}_{44414}\right] \mathrm{Cl}$ were taken from the IL OPLS-AA all-atom force field developed by Canongia Lopes and Padua [74] and water molecules were represented by the SPC/E model [75]. In all simulations, acetic acid was considered as protonated and its parameter was taken from the OPLS-AA forcefield. Cubic boxes with periodic boundary conditions were used placing all the molecules randomly, followed by an equilibrium process. All systems contain $200\left[\mathrm{P}_{44414}\right] \mathrm{Cl}$ ion pairs, 580 acetic acid molecules and a varied number of water molecules. The composition of the system simulated are summarised in Table 2 . For all simulations, the following equilibration protocol was followed: an energy minimization step using the steepest descent algorithm to prevent short-range contacts between atoms prior to two short equilibrium runs in the NVT and NpT ensembles, respectively. Afterwards, all systems were run for $100 \mathrm{~ns}$ of simulation time in the NpT ensemble. Simulation outputs were visualized using the VMD software package [76] and the spatial distribution functions (SDF) and domain analysis were analyzed using the TRAVIS package [54,55].

\section{Conclusions}

The phase diagram of the $\left[\mathrm{P}_{44414}\right] \mathrm{Cl}+\mathrm{CH}_{3} \mathrm{COOH}+\mathrm{H}_{2} \mathrm{O}$ system is studied here for the first time, it being shown that the system presents an unusual "type 0 " closed phase diagram and an LCST type behavior. MD simulations of the $\left[\mathrm{P}_{44414}\right] \mathrm{Cl}+\mathrm{CH}_{3} \mathrm{COOH}$ system indicate that the formation of the biphasic regime is due to a "washing-out" phenomenon upon addition of water, driven by water nanostructuring ultimately resulting in solvophobic segregation of the $\left[\mathrm{P}_{44414}\right] \mathrm{Cl}$ with acetic acid. This behavior is markedly different from conventional IL-salt, polymer-IL or even IL-inorganic acid aqueous biphasic system [65]. The $\left[\mathrm{P}_{44414}\right] \mathrm{Cl}+\mathrm{CH}_{3} \mathrm{COOH}$ system, in the absence of additional water, presents a good solubility for $\mathrm{CoO}$ as well as for $\mathrm{Nd}_{2} \mathrm{O}_{3}$. UV-vis analyses indicate varied metal speciation in the mixture from anionic chlorometallate complexes for $\mathrm{Co}(\mathrm{II})$ and $\mathrm{Fe}(\mathrm{III})$, acetate $\mathrm{Nd}(\mathrm{III})$ specie to more complex speciation in the case of $\mathrm{Ni}(\mathrm{II})$. 
The $\left[\mathrm{P}_{44414}\right] \mathrm{Cl}+\mathrm{CH}_{3} \mathrm{COOH}$ system was applied to the treatment of real waste NiMH battery black mass, with the integration of the leaching and separation steps achieved by the simple addition of water to the leachate yielding a biphasic regime that allows one of the phases to become enriched in $\mathrm{Co}(\mathrm{II})$. Both the leaching and metal separation steps are selective for $\mathrm{Co}(\mathrm{II})$ against $\mathrm{Ni}$ (II), $\mathrm{Mn}$ (II) and the rare earth elements. Furthermore, extraction in the $\left[\mathrm{P}_{44414}\right] \mathrm{Cl}+\mathrm{CH}_{3} \mathrm{COOH}$ presents an interesting selectivity for $\mathrm{Co}$ (II) against Fe(III). However, additional separation steps are required for the separation of $\mathrm{Co}$ (II) from $\mathrm{Zn}$ (II) and $\mathrm{Mn}$ (II). The close to fourfold concentration of $\mathrm{Co}$ (II) from leaching to separation in a single solution through the simple addition of water greatly simplifies downstream purification and provides a guideline for metal process intensification in other alternative solvents such as DES.

Supplementary Materials: Figure S1: 3D spatial density function (SDF) plot of the $\left[\mathrm{P}_{44414}\right] \mathrm{Cl}+\mathrm{CH}_{3} \mathrm{COOH}$ $+\mathrm{H}_{2} \mathrm{O}$ system for two different water content; Figure S2: Domain analysis of the $\mathrm{CH}_{3} \mathrm{COOH} \mathrm{Cl}^{-}$subset based on the Voronoi tessellation method; Figure S3: Standardised coordination numbers $(\mathrm{CNs})$ between $\left[\mathrm{P}_{44414}\right]^{+}$ and $\mathrm{CH}_{3} \mathrm{COOH}$ or $\mathrm{Cl}^{-}$as a function of the water content; Figure S4: Average diameter of $\left[\mathrm{P}_{44414}\right]^{+}$aggregates (20.0 wt.\% IL) in the presence of acetic acid as estimated by dynamic light scattering; Table S1: Distribution coefficients in the biphasic $\left[\mathrm{P}_{44414}\right] \mathrm{Cl}+\mathrm{CH}_{3} \mathrm{COOH}+\mathrm{H}_{2} \mathrm{O}$ of the principal metals in the NiMH leachate.

Author Contributions: J.A.P.C. and N.S. supervised the work and analyzed the data. S.J.R.V., N.S. and H.P. obtained and analyzed the data. All authors participated in the writing of the manuscript. All authors have read and agreed to the published version of the manuscript.

Funding: This work was developed within the scope of the project CICECO-Aveiro Institute of Materials, UIDB/50011/2020 and UIDP/50011/2020, financed by national funds through the Portuguese Foundation for Science and Technology/MCTES. H. Passos acknowledges FCT (Fundação para a Ciência e a Tecnologia), I.P., under the Scientific Employment Stimulus-Individual Call-CEECIND/00831/2017—under the CEEC Individual 2017. N. Schaeffer acknowledges the national funds (OE), through FCT (Fundação para a Ciência e a Tecnologia), I.P., in the scope of the framework contract foreseen in the numbers 4, 5 and 6 of the article 23, of the Decree-Law 57/2016, of August 29, changed by Law 57/2017, of July 19.

Conflicts of Interest: The authors declare no conflict of interest.

\section{References}

1. Binnemans, K.; Jones, P.T. Solvometallurgy: An Emerging Branch of Extractive Metallurgy. J. Sustain. Metall. 2017, 3, 570-600. [CrossRef]

2. Lin, W.; Zhang, R.-W.; Jang, S.E.J.S.S.; Wong, C.-P.; Hong, J.-I. “Organic Aqua Regia"-Powerful Liquids for Dissolving Noble Metals. Angew. Chem. Int. Ed. 2010, 49, 7929-7932. [CrossRef] [PubMed]

3. Räisänen, M.; Heliövaara, E.; Al-Qaisi, F.; Muuronen, M.; Eronen, A.; Liljeqvist, H.; Nieger, M.; Kemell, M.; Moslova, K.; Hämäläinen, J.; et al. Pyridinethiol-Assisted Dissolution of Elemental Gold in Organic Solutions. Angew. Chem. Int. Ed. 2018, 57, 17104-17109. [CrossRef] [PubMed]

4. Abbott, A.P.; Frisch, G.; Gurman, S.J.; Hillman, A.R.; Hartley, J.; Holyoak, F.; Ryder, K.S. Ionometallurgy: Designer redox properties for metal processing. Chem. Comm. 2011, 47, 10031-10033. [CrossRef]

5. Hartley, J.M.; Ip, C.-M.; Forrest, G.C.H.; Singh, K.; Gurman, S.J.; Ryder, K.S.; Abbott, A.P.; Frisch, G. EXAFS Study into the Speciation of Metal Salts Dissolved in Ionic Liquids and Deep Eutectic Solvents. Inorg. Chem. 2014, 53, 6280-6288. [CrossRef] [PubMed]

6. Abbott, A.P.; Capper, G.; Davies, D.L.; Rasheed, R.K. Ionic Liquid Analogues Formed from Hydrated Metal Salts. Chem. Eur. J. 2004, 10, 3769-3774. [CrossRef] [PubMed]

7. Abbott, A.P.; Harris, R.C.; Holyoak, F.; Frisch, G.; Hartley, J.; Jenkin, G.R.T. Electrocatalytic recovery of elements from complex mixtures using deep eutectic solvents. Green Chem. 2015, 17, 2172-2179. [CrossRef]

8. Jenkin, G.R.; Al-Bassam, A.Z.; Harris, R.C.; Abbott, A.P.; Smith, D.J.; Holwell, D.A.; Chapman, R.J.; Stanley, C.J. The application of deep eutectic solvent ionic liquids for environmentally-friendly dissolution and recovery of precious metals. Miner. Eng. 2016, 87, 18-24. [CrossRef]

9. Abbott, A.P.; Al-Bassam, A.Z.M.; Goddard, A.; Harris, R.C.; Jenkin, G.R.T.; Nisbet, F.J.; Wieland, M. Dissolution of pyrite and other Fe-S-As minerals using deep eutectic solvents. Green Chem. 2017, 19, 2225-2233. [CrossRef]

10. Anggara, S.; Bevan, F.; Harris, R.C.; Hartley, J.M.; Frisch, G.; Jenkin, G.R.T.; Abbott, A.P. Direct extraction of copper from copper sulfide minerals using deep eutectic solvents. Green Chem. 2019, 21, 6502-6512. [CrossRef] 
11. Zürner, P.; Frisch, G. Leaching and Selective Extraction of Indium and Tin from Zinc Flue Dust Using an Oxalic Acid-Based Deep Eutectic Solvent. ACS Sustain. Chem. Eng. 2019, 7, 5300-5308. [CrossRef]

12. Abbott, A.P.; Frisch, G.; Hartley, J.; Ryder, K.S. Processing of metals and metal oxides using ionic liquids. Green Chem. 2011, 13, 471-481. [CrossRef]

13. Rodriguez, N.R.; Machiels, L.; Binnemans, K. p-Toluenesulfonic Acid-Based Deep-Eutectic Solvents for Solubilizing Metal Oxides. ACS Sustain. Chem. Eng. 2019, 7, 3940-3948. [CrossRef]

14. Damilano, G.; Laitinen, A.; Willberg-Keyriläinen, P.; Lavonen, T.; Häkkinen, R.; Dehaen, W.; Binnemans, K.; Kuutti, L. Effects of thiol substitution in deep-eutectic solvents (DESs) as solvents for metal oxides. RSC Adv. 2020, 10, 23484-23490. [CrossRef]

15. Abbott, A.P.; Capper, G.; Davies, D.L.; McKenzie, K.J.; Obi, S.U. Solubility of Metal Oxides in Deep Eutectic Solvents Based on Choline Chloride. J. Chem. Eng. Data 2006, 51, 1280-1282. [CrossRef]

16. Jiang, J.; Bai, X.; Zhao, X.; Chen, W.; Yu, T.; Li, Y.; Mu, T. Poly-quasi-eutectic solvents (PQESs): Versatile solvents for dissolving metal oxides. Green Chem. 2019, 21, 5571-5578. [CrossRef]

17. Smith, D.F.; A Gucinski, J. Synthetic silver oxide and mercury-free zinc electrodes for silver-zinc reserve batteries. J. Power Sources 1999, 80, 66-71. [CrossRef]

18. Zhang, Q.; Wang, Q.; Zhang, S.; Lu, X.; Zhang, X. Electrodeposition in Ionic Liquids. ChemPhysChem 2015, 17, 335-351. [CrossRef]

19. Smith, E.L.; Abbott, A.P.; Ryder, K.S. Deep Eutectic Solvents (DESs) and Their Applications. Chem. Rev. 2014, 114, 11060-11082. [CrossRef]

20. Van Osch, D.J.; Zubeir, L.F.; Bruinhorst, A.A.V.D.; Da Rocha, M.M.A.; Kroon, M.C. Hydrophobic deep eutectic solvents as water-immiscible extractants. Green Chem. 2015, 17, 4518-4521. [CrossRef]

21. Phelps, T.E.; Bhawawet, N.; Jurisson, S.S.; Baker, G.A. Efficient and Selective Extraction of 99mTcO4- from Aqueous Media Using Hydrophobic Deep Eutectic Solvents. ACS Sustain. Chem. Eng. 2018, 6, 13656-13661. [CrossRef]

22. Tereshatov, E.E.; Boltoeva, M.Y.; Folden, C.M. First evidence of metal transfer into hydrophobic deep eutectic and low-transition-temperature mixtures: Indium extraction from hydrochloric and oxalic acids. Green Chem. 2016, 18, 4616-4622. [CrossRef]

23. Rodriguez, N.R.; Machiels, L.; Onghena, B.; Spooren, J.; Binnemans, K. Selective recovery of zinc from goethite residue in the zinc industry using deep-eutectic solvents. RSC Adv. 2020, 10, 7328-7335. [CrossRef]

24. Söldner, A.; Zach, J.; König, B. Deep eutectic solvents as extraction media for metal salts and oxides exemplarily shown for phosphates from incinerated sewage sludge ash. Green Chem. 2019, 21, 321-328. [CrossRef]

25. Riaño, S.; Petranikova, M.; Onghena, B.; Hoogerstraete, T.V.; Banerjee, D.; Foreman, M.R.S.-J.; Ekberg, C.; Binnemans, K. Separation of rare earths and other valuable metals from deep-eutectic solvents: A new alternative for the recycling of used NdFeB magnets. RSC Adv. 2017, 7, 32100-32113. [CrossRef]

26. Landa-Castro, M.; Aldana-González, J.; De Oca-Yemha, M.M.; Romero-Romo, M.; Arce-Estrada, E.; Palomar-Pardavé, M. Ni-Co alloy electrodeposition from the cathode powder of Ni-MH spent batteries leached with a deep eutectic solvent (reline). J. Alloys Compd. 2020, 830, 154650. [CrossRef]

27. Tran, M.K.; Rodrigues, M.-T.F.F.; Kato, K.; Babu, G.; Ajayan, P.M. Deep eutectic solvents for cathode recycling of Li-ion batteries. Nat. Energy 2019, 4, 339-345. [CrossRef]

28. Wang, S.; Zhang, Z.; Lu, Z.; Xu, Z. A novel method for screening deep eutectic solvent to recycle the cathode of Li-ion batteries. Green Chem. 2020, 22, 4473-4482. [CrossRef]

29. Peeters, N.; Binnemans, K.; Riaño, S. Solvometallurgical recovery of cobalt from lithium-ion battery cathode materials using deep-eutectic solvents. Green Chem. 2020, 22, 4210-4221. [CrossRef]

30. Passos, H.; Tavares, D.J.P.; Ferreira, A.M.; Freire, M.G.; Coutinho, J.A.P. Are Aqueous Biphasic Systems Composed of Deep Eutectic Solvents Ternary or Quaternary Systems? ACS Sustain. Chem. Eng. 2016, 4, 2881-2886. [CrossRef]

31. Spathariotis, S.; Peeters, N.; Ryder, K.S.; Abbott, A.P.; Binnemans, K.; Riaño, S. Separation of iron(iii), zinc(ii) and lead(ii) from a choline chloride-ethylene glycol deep eutectic solvent by solvent extraction. RSC Adv. 2020, 10, 33161-33170. [CrossRef]

32. Cherigui, E.A.M.; Sentosun, K.; Mamme, M.H.; Lukaczynska, M.; Terryn, H.A.; Bals, S.; Ustarroz, J. On the Control and Effect of Water Content during the Electrodeposition of Ni Nanostructures from Deep Eutectic Solvents. J. Phys. Chem. C 2018, 122, 23129-23142. [CrossRef] 
33. Hammond, O.S.; Bowron, D.T.; Edler, K.J. The Effect of Water upon Deep Eutectic Solvent Nanostructure: An Unusual Transition from Ionic Mixture to Aqueous Solution. Angew. Chem. Int. Ed. 2017, 56, 9782-9785. [CrossRef]

34. Florindo, C.; Branco, L.C.; Marrucho, I.M. Quest for Green-Solvent Design: From Hydrophilic to Hydrophobic (Deep) Eutectic Solvents. ChemSusChem 2019, 12, 1549-1559. [CrossRef]

35. Saita, S.; Kohno, Y.; Ohno, H. Detection of small differences in the hydrophilicity of ions using the LCST-type phase transition of an ionic liquid-water mixture. Chem. Commun. 2012, 49, 93-95. [CrossRef]

36. Dong, D.; Hooper, J.B.; Bedrov, D. Structural and Dynamical Properties of Tetraalkylammonium Bromide Aqueous Solutions: A Molecular Dynamics Simulation Study Using a Polarizable Force Field. J. Phys. Chem. B 2017, 121, 4853-4863. [CrossRef]

37. Kumar, S.; Aswal, V.K.; Naqvi, A.Z.; Goyal, P.S.; Din, K.U. Cloud Point Phenomenon in Ionic Micellar Solutions: A SANS Study. Langmuir 2001, 17, 2549-2551. [CrossRef]

38. Schaeffer, N.; Pérez-Sánchez, G.; Passos, H.; Gomes, J.R.; Papaiconomou, N.; Coutinho, J.A.P. Mechanisms of phase separation in temperature-responsive acidic aqueous biphasic systems. Phys. Chem. Chem. Phys. 2019, 21, 7462-7473. [CrossRef]

39. Longeras, O.; Gautier, A.; Ballerat-Busserolles, K.; Andanson, J.-M. Deep Eutectic Solvent with Thermo-Switchable Hydrophobicity. ACS Sustain. Chem. Eng. 2020, 8, 12516-12520. [CrossRef]

40. European Commission; The Commission to the European Parliament, the Council; The European Economic and Social Committee; The Committee of the Regions. Critical Raw Materials Resilience: Charting a Path towards Greater Security and Sustainability; European Commission: Brussels, Belgium, 2020; Available online: https://ec.europa.eu/info/index_en (accessed on 3 September 2020).

41. Fu, X.; Beatty, D.N.; Gaustad, G.; Ceder, G.; Roth, R.; Kirchain, R.E.; Bustamante, M.; Babbitt, C.W.; Olivetti, E. Perspectives on Cobalt Supply through 2030 in the Face of Changing Demand. Environ. Sci. Technol. 2020, 54, 2985-2993. [CrossRef]

42. Pateli, I.M.; Thompson, D.; Alabdullah, S.S.M.; Abbott, A.P.; Jenkin, G.R.T.; Hartley, J.M. The effect of pH and hydrogen bond donor on the dissolution of metal oxides in deep eutectic solvents. Green Chem. 2020, 22, 5476-5486. [CrossRef]

43. Golmohammadzadeh, R.; Faraji, F.; Rashchi, F. Recovery of lithium and cobalt from spent lithium ion batteries (LIBs) using organic acids as leaching reagents: A review. Resour. Conserv. Recycl. 2018, 136, 418-435. [CrossRef]

44. Ruggeri, S.; Poletti, F.; Zanardi, C.; Pigani, L.; Zanfrognini, B.; Corsi, E.; Dossi, N.; Salomäki, M.; Kivelä, H.; Lukkari, J.; et al. Chemical and electrochemical properties of a hydrophobic deep eutectic solvent. Electrochim. Acta 2019, 295, 124-129. [CrossRef]

45. Florindo, C.; Branco, L.; Marrucho, I. Development of hydrophobic deep eutectic solvents for extraction of pesticides from aqueous environments. Fluid Ph. Equilib. 2017, 448, 135-142. [CrossRef]

46. Gras, M.; Papaiconomou, N.; Schaeffer, N.; Chainet, E.; Tedjar, F.; Coutinho, J.A.P.; Billard, I. Ionic-Liquid-Based Acidic Aqueous Biphasic Systems for Simultaneous Leaching and Extraction of Metallic Ions. Angew. Chem. Int. Ed. 2018, 57, 1563-1566. [CrossRef]

47. Tomé, L.I.N.; Pereira, J.F.B.; Rogers, R.D.; Freire, M.G.; Gomes, J.R.; Coutinho, J.A.P. “Washing-out” ionic liquids from polyethylene glycol to form aqueous biphasic systems. Phys. Chem. Chem. Phys. 2014, 16, 2271. [CrossRef]

48. Neves, C.M.S.S.; Shahriari, S.; Lemus, J.; Pereira, J.F.B.; Freire, M.G.; Coutinho, J.A.P. Aqueous biphasic systems composed of ionic liquids and polypropylene glycol: Insights into their liquid-liquid demixing mechanisms. Phys. Chem. Chem. Phys. 2016, 18, 20571-20582. [CrossRef]

49. Qiao, Y.; Ma, W.; Theyssen, N.; Chen, C.; Hou, Z. Temperature-Responsive Ionic Liquids: Fundamental Behaviors and Catalytic Applications. Chem. Rev. 2017, 117, 6881-6928. [CrossRef]

50. Sangster, J. Octanol-Water Partition Coefficients of Simple Organic Compounds. J. Phys. Chem. Ref. Data 1989, 18, 1111-1229. [CrossRef]

51. Cláudio, A.F.M.; Neves, M.C.; Shimizu, K.; Lopes, J.N.C.; Freire, M.G.; Coutinho, J.A.P. The magic of aqueous solutions of ionic liquids: Ionic liquids as a powerful class of catanionic hydrotropes. Green Chem. 2015, 17, 3948-3963. [CrossRef] 
52. Posada, E.; López-Salas, N.; Riobóo, R.J.J.; Ferrer, M.L.; Gutiérrez, M.C.; Del Monte, F. Reline aqueous solutions behaving as liquid mixtures of H-bonded co-solvents: Microphase segregation and formation of co-continuous structures as indicated by Brillouin and 1H NMR spectroscopies. Phys. Chem. Chem. Phys. 2017, 19, 17103-17110. [CrossRef] [PubMed]

53. Kuddushi, M.; Nangala, G.S.; Rajput, S.; Ijardar, S.P.; Malek, N.I. Understanding the peculiar effect of water on the physicochemical properties of choline chloride based deep eutectic solvents theoretically and experimentally. J. Mol. Liq. 2019, 278, 607-615. [CrossRef]

54. Brehm, M.; Kirchner, B. TRAVIS - A Free Analyzer and Visualizer for Monte Carlo and Molecular Dynamics Trajectories. J. Chem. Inf. Model. 2011, 51, 2007-2023. [CrossRef] [PubMed]

55. Brehm, M.; Weber, H.; Thomas, M.; Hollóczki, O.; Kirchner, B. Domain Analysis in Nanostructured Liquids: A Post-Molecular Dynamics Study at the Example of Ionic Liquids. ChemPhysChem 2015, 16, 3271-3277. [CrossRef]

56. Konings, R.J.M.; Beneš, O. The Thermodynamic Properties of the f-Elements and Their Compounds. I. The Lanthanide and Actinide Metals. J. Phys. Chem. Ref. Data 2010, 39, 043102. [CrossRef]

57. Chen, W.; Jiang, J.; Lan, X.; Zhao, X.; Mou, H.; Mu, T. A strategy for the dissolution and separation of rare earth oxides by novel Brønsted acidic deep eutectic solvents. Green Chem. 2019, 21, 4748-4756. [CrossRef]

58. Liu, W.; Etschmann, B.; Brugger, J.; Spiccia, L.; Foran, G.; McInnes, B. UV-Vis spectrophotometric and XAFS studies of ferric chloride complexes in hyper-saline $\mathrm{LiCl}$ solutions at $25-90^{\circ} \mathrm{C}$. Chem. Geol. 2006, 231, 326-349. [CrossRef]

59. Zhang, N.; Brugger, J.; Etschmann, B.; Ngothai, Y.; Zeng, D. Thermodynamic Modeling of Poorly Complexing Metals in Concentrated Electrolyte Solutions: An X-Ray Absorption and UV-Vis Spectroscopic Study of $\mathrm{Ni}(\mathrm{II})$ in the NiCl2-MgCl2-H2O System. PLoS ONE 2015, 10, e0119805. [CrossRef]

60. Nockemann, P.; Thijs, B.; Parac-Vogt, T.N.; Van Hecke, K.; Van Meervelt, L.; Tinant, B.; Hartenbach, I.; Schleid, T.; Ngan, V.T.; Nguyen, M.T.; et al. Carboxyl-Functionalized Task-Specific Ionic Liquids for Solubilizing Metal Oxides. Inorg. Chem. 2008, 47, 9987-9999. [CrossRef]

61. Fagnant, J.D.P.; Goff, G.S.; Scott, B.L.; Runde, W.; Brennecke, J.F. Switchable Phase Behavior of [HBet][Tf2N]-H2O upon Neodymium Loading: Implications for Lanthanide Separations. Inorg. Chem. 2013, 52, 549-551. [CrossRef]

62. Zanonato, P.L.; Di Bernardo, P.; Bismondo, A.; Rao, L.; Choppin, G.R. Thermodynamic Studies of the Complexation between Neodymium and Acetate at Elevated Temperatures. J. Solut. Chem. 2001, 30, 1-18. [CrossRef]

63. Gammons, C.; Wood, S.; Williams-Jones, A. The aqueous geochemistry of the rare earth elements and yttrium: VI. Stability of neodymium chloride complexes from 25 to $300^{\circ} \mathrm{C}$. Geochim. Cosmochim. Acta 1996, 60, 4615-4630. [CrossRef]

64. Fernandes, A.; Afonso, J.C.; Dutra, A.J.B. Separation of nickel(II), cobalt(II) and lanthanides from spent $\mathrm{Ni}-\mathrm{MH}$ batteries by hydrochloric acid leaching, solvent extraction and precipitation. Hydrometallurgy 2013, 133, 37-43. [CrossRef]

65. Schaeffer, N.; Gras, M.; Passos, H.; Mogilireddy, V.; Mendonça, C.M.N.; Pereira, E.; Chainet, E.; Billard, I.; Coutinho, J.A.P.; Papaiconomou, N. (N.) Synergistic Aqueous Biphasic Systems: A New Paradigm for the “One-Pot" Hydrometallurgical Recovery of Critical Metals. ACS Sustain. Chem. Eng. 2018, 7, 1769-1777. [CrossRef]

66. Larsson, K.; Binnemans, K. Selective extraction of metals using ionic liquids for nickel metal hydride battery recycling. Green Chem. 2014, 16, 4595-4603. [CrossRef]

67. Lommelen, R.; Hoogerstraete, T.V.; Onghena, B.; Billard, I.; Binnemans, K. Model for Metal Extraction from Chloride Media with Basic Extractants: A Coordination Chemistry Approach. Inorg. Chem. 2019, 58, 12289-12301. [CrossRef]

68. Abraham, M.J.; Murtola, T.; Schulz, R.; Páll, S.; Smith, J.C.; Hess, B.; Lindahl, E. GROMACS: High performance molecular simulations through multi-level parallelism from laptops to supercomputers. SoftwareX 2015, 1-2, 19-25. [CrossRef]

69. Hockney, R.; Goel, S.; Eastwood, J. Quiet high-resolution computer models of a plasma. J. Comput. Phys. 1974, 14, 148-158. [CrossRef]

70. Hess, B.; Bekker, H.; Berendsen, H.J.C.; Fraaije, J.G.E.M. LINCS: A Linear Constraint Solver for molecular simulations. J. Comput. Chem. 1997, 18, 1463-1472. [CrossRef] 
71. Evans, D.J.; Holian, B.L. The Nose-Hoover thermostat. J. Chem. Phys. 1985, 83, 4069-4074. [CrossRef]

72. Parrinello, M.; Rahman, A. Polymorphic transitions in single crystals: A new molecular dynamics method. J. Appl. Phys. 1981, 52, 7182-7190. [CrossRef]

73. A Darden, T.; York, D.M.; Pedersen, L. Particle mesh Ewald: AnN·log(N) method for Ewald sums in large systems. J. Chem. Phys. 1993, 98, 10089-10092. [CrossRef]

74. Lopes, J.N.C.; Pádua, A.A.H. Molecular Force Field for Ionic Liquids III: Imidazolium, Pyridinium, and Phosphonium Cations; Chloride, Bromide, and Dicyanamide Anions. J. Phys. Chem. B 2006, 110, 19586-19592. [CrossRef]

75. Berendsen, H.J.C.; Grigera, J.R.; Straatsma, T.P. The missing term in effective pair potentials. J. Phys. Chem. 1987, 91, 6269-6271. [CrossRef]

76. Humphrey, W.; Dalke, A.; Schulten, K. VMD: Visual molecular dynamics. J. Mol. Graph. 1996, 14, 33-38. [CrossRef]

Sample Availability: Samples of the compounds are available from the authors upon reasonable request if available.

Publisher's Note: MDPI stays neutral with regard to jurisdictional claims in published maps and institutional affiliations.

(C) 2020 by the authors. Licensee MDPI, Basel, Switzerland. This article is an open access article distributed under the terms and conditions of the Creative Commons Attribution (CC BY) license (http://creativecommons.org/licenses/by/4.0/). 